\title{
Social capital: a fresh vision for public libraries in South Africa?
}

\author{
Genevieve Hart' \\ Department of Library \& Information Science, \\ University of the Western Cape \\ ghart@uwc.ac.za
}

\begin{abstract}
Received: $9^{\text {th }}$ January 2007
Accepted: $8^{\text {th }}$ February 2007

The article argues that the construct of social capital offers South African public librarianship fresh vision - urgently needed if it is to fulfil its potential role in social inclusion. Social capital refers to the stocks of social trust, norms and networks that a community can draw on to solve common problems. A wide body of research in Southern Africa bears witness to its role in the success of development projects. Restrictive economic policies, coupled with new demands, have put pressure on public libraries and research points to a prevailing low morale among their staff, who, it is suggested, find themselves caught in the transition towards new models of service. Government's acceptance of social capital as a crucial tool in the developmental state and the news of its intervention to transform South African public libraries suggest the need to articulate the library as "a place for all". In reaction to neglect in the literature of social capital, internationally, librarians have documented their building of social capital through their education, information and community programmes. This work offers South African librarians a rich resource to draw on in their search for new direction and vision.
\end{abstract}

Keywords: Social capital; South Africa; Public libraries

\section{Introduction}

The article argues that the rise in the 1990s of the notion of "social capital", the stocks of social trust, norms and networks that people can draw upon to solve common problems (Civic Practices Network 2004), might provide South African public librarianship with a renewed philosophical framework. Recent South African government thinking has made much of the concept of the "developmental state" and the links between community development and social capital. The notion of social capital, therefore, might provide both a visionary and timely hook upon which South African public librarianship might hang its social mission.

Since 2000, librarians across the world have engaged in debate on their role in social capital - galvanised by the publication in the United States of Robert Putnam's landmark book Bowling Alone (2000) which ignored the social role of public libraries. The outcome of Putnam's neglect has been a sharper focus within public library circles internationally on what it is that public libraries contribute to society. However, the South African library literature holds only one or two passing references to social capital, usually in the context of discussions of broader concepts such as social inclusion (for example Stilwell 2006) and social justice (for example Britz 2004). And these concepts do not feature in the professional documentation of the Library and Information Association of South Africa (LIASA). In her recent discussion of the significance of the concept of social inclusion for South African librarianship, Stilwell attributes this disregard to fears that such notions as "exclusion" might not sit well with the high rhetoric of our new democracy (2006: 23). But, given the widespread recognition of the pertinence of these concepts to South African society in other sectors including government, an alternative explanation might be that the introspection of the South African library profession, resulting from its preoccupation with survival issues in recent years, has immobilised constructive engagement with potentially positive trends outside its immediate ambit.

However, the announcements in 2005 that the South African government is to allocate over Ibillion rands to public libraries, but only after extensive research into the sector, and that the National Council of Library and Information Services (NCLIS) is to draw up a new charter for the profession might act as a catalyst for vision-building. A vision provides an organisation or group with a forward-looking image of itself that moves outside old assumptions. Mission, goals and strategies begin with a vision - the shared ideal towards which a group aspires. Whether South African public librarians, who have undergone a period of shrinking resources and increased demands, have a shared vision is questionable. Kagan's study of South African librarians led him to warn in 2002 that doubt over professional identity might hinder their credibility in negotiating new social roles (2002: 2). The author, herself, has found widespread ambivalence among public librarians about shifts in emphasis in public library work, which emanates largely from uncertainty over the appropriateness of the strongly educational role that many feel has "fallen" on them (Hart 2006b). Arguably, only if it is

I. Genevieve Hart (PhD) is Associate Professor and Chair of the Department of Library and Information Science, University of Western Cape, South Africa 
sure of its own identity, can public librarianship sell itself to the others upon whom it depends for its continued existence - educationists, government officials, community leaders, for example.

The article follows the example of the Public and Community Libraries Inventory of South Africa (PaCLISA) report (Van Helden \& Lor 2002: 2) in making no distinction between public libraries and community libraries. As the PaCLISA report points out, public libraries are increasingly taking the name "community libraries", which in the 1980s denoted libraries set up by NGOs and community based organisations as part of the struggle against apartheid (Stilwell 200I: 203). The adoption of the name "community libraries" could signal a new conceptualisation of the role of public libraries in society, with a stronger emphasis on the community participation of the 1980s community resource centres.

\section{In need of fresh vision? South African public librarianship since 1994}

The title begs the question: Do South African public libraries need a "fresh" vision? A study of public libraries in South Africa post 1994 has to acknowledge two simultaneous and, perhaps, conflicting forces for change: the internal transformation to democracy in the early 1990s, which led to calls for a new model of public library which might contribute more dynamically to socio-economic development; and the forces of the globalised market economy. In his analysis of the weakening position of public libraries, Dick (2002: 29) criticises the naivete of South African librarians, who, he claims, operate unconsciously from within a positivist paradigm and so see libraries as objective neutral realities isolated from their political and economic contexts. This article argues that the quest for a new vision, which had begun in the late 1980s, stalled in the mid 1990s, owing to national economic policy and upheavals in local government.

In retrospect, the late 1980s and early 1990s was a hopeful time for South African librarianship. As in all other areas of society, the looming demise of the apartheid government led to lively debate within librarianship on the future of libraries. Various think-tanks, supported directly and indirectly by the government-in-waiting, the African National Congress, produced position papers. Public libraries in particular received attention. In common with other former British colonies, South African public libraries were moulded in the British tradition. They are unevenly distributed, designed to serve an educated and urban middle class - with, on average, less than $10 \%$ of the population signed-up members (Van Helden \& Lor 2002). In the early 1990s, there was talk of a new "radical" and African model that would contribute to the national reconstruction and development (RDP) programme (National Education Policy Investigation (NEPI). Library and Information Services Research Group 1992: 55-56). A key element of NEPI's radical philosophy of public librarianship was acceptance of a "developmental" model, in which information is seen as a "key element in the implementation and sustenance of democracy and the education and empowerment of people" (p. 55). Some evidence that librarians supported the developmental model is Stilwell's study in 1996 of the views of professionally qualified librarians, working within the provincial public library services, the majority of whom responded positively to the idea of a transformed social mission (1996).

However, the optimism of the early 1990s might well have been dampened by the stringent cuts in public library spending which followed South Africa's adoption of the values of the global market economy (Stilwell 2001: 203; Dick 2002: 30). In 1998, Lor, then Head of South Africa's National Library and Chair of the Transitional Executive Committee of the new professional association LIASA, contended in a submission to Parliament that budget cut-backs were "crippling" libraries (Lor 1998). He described deterioration in all sectors of libraries since 1994 but concentrated on the challenges facing public libraries. Leach's follow-up provincial survey found widespread rationalising and downsizing of staff. All but one public library service reported a reduction in their funding, with resulting cuts in materials budgets, staff, and training. Another significant finding was an increase in spending on educational materials in an effort to provide for the needs of students and scholars.

Since the late 1990s, there has been comment in the South African research and professional literature that the shortage of school libraries across the educational spectrum, coupled with the introduction of a resource-based national curriculum, has put increased pressure on public libraries (for example Maepa \& Mhinga 2003; Hart 2004). The challenge is not only to provide enough materials but also to cope with learners' lack of information skills. The author's research suggests that South African public librarians were unprepared for the new curriculum and, indeed, many feel victimised by it (Hart 2004; 2006b). A common complaint is that public libraries are expected to take on enhanced responsibilities but without recognition or increase in resources.

In 200I, Kagan's survey of South African librarians' "opinion" on a possible shift in their mission towards "social responsibilities" found less positive support than Stilwell's 1996 study. The more negative attitudes might reflect the shifts in political economic climate towards what he calls "neo-liberalism", the deterioration in the position of libraries in the 1990s and his wider sample of respondents, which included public library staff working within the municipalities. Kagan warns that low levels of professional education might hamper innovation (2002: 2). He contends that in countries where librarians' status is low, they cannot maximise their potential societal benefits as they lack credibility amongst policy-

SA Jnl Libs \& Info Sci 2007, 73(1) 
makers. Some four years later, the author's interviews with 57 public library staff members in Mpumalanga Province lend support to Kagan's warnings. She found evidence of ad-hoc appointments by local government of under-qualified and under-educated staff, resulting doubts among remaining qualified professionals over their future and a pervasive low morale (Hart 2006b).

Two aspects of change in public library governance since the late 1990s are responsible for the low morale - the restructuring of local authorities and legal ambiguity over the funding of public libraries. Former small town libraries now find themselves mere branch libraries - after the merging of towns and rural settlements into the new sprawling local municipalities. The author's study of public libraries in Mpumalanga Province in 2004 uncovered dissatisfaction among staff, concerned over the loss of their autonomy, the unmanageable size of the new municipalities and shortages of staff (Hart 2005: 145). The aim of the restructuring is to overcome the inequities between the advantaged (historically white) areas and the disadvantaged black townships and rural settlements, and, arguably, the larger municipalities offer libraries new opportunities. However, concern over the capacity of local authorities to fulfil their developmental mandate is evident. Butler, Professor of Political Studies at the University of Cape Town, describes South African local government as having "the most troubled history" and as facing "the starkest challenges" of the three sectors of government (2004: 101). Leach (2006: 132) warns that, given the huge challenges facing local authorities in providing basic services, public libraries might be forced to find alternative sources of funding.

The second aspect of public library governance to provoke anxiety post 1994 is the impasse with regard to funding. The 1996 Constitution defines public libraries as a solely provincial responsibility and ignores the pre- 1994 provincial ordinances that put the funding for staff and day-to-day administration in the hands of the third tier of government, the municipalities. At present, money spent by local authorities on libraries is unauthorised expenditure in terms of public finance legislation (The Print Industries Cluster Council Working Group on Libraries 2005: 87) and, indeed, there is evidence that some authorities are cutting their library budgets. A sense of insecurity will prevail until this anomaly has been resolved and it is good news that the Department of Arts and Culture is now investigating a new funding model for public libraries (Dominy 2006).

In 200I, the School of Human and Social Studies at the University of Natal (Pietermaritzburg) returned to the debates of the early 1990s in a collection of articles which explore the connections between development and information (Stilwell, Leach and Burton 200I). The book provides a more sober analysis than the documents of the early 1990s, with the editors warning that the two notions "information" and "development" are contested ones and that there is no linear relationship between information and development. Or is it perhaps that research has not, as yet, convincingly documented the socio-economic impact of information on a community? In response to this question, in his chapter, Mchombu (2001: 237) contends that his research in community information centres in rural Malawi and Tanzania, indeed shows that a developmental model for libraries is possible, in which a positive relationship between development and information and information centre (or library) is constructed. The model depends, however, on the information centre staff's being prepared to offer more than passive "reading room services".

South African public librarians, of course, would claim to offer more than reading room services. The mission statements and conference themes of the national association, LIASA, highlight their aspirations to play a role in the development of individuals, both "literate and illiterate" and of communities. However, two questions are pertinent:

- Is there documented evidence of the developmental role of public libraries?

- And, if the answer to the first question is positive, how well-recognised is this role? For example, has the new generation of government officials shifted its perceptions of the public library since the 1980s, when the Zaaiman survey of South African public libraries found extremely limited conceptions of the role of the public library among its local government respondents (Zaaiman, Roux \& Rykheer 1988).

The purpose in this article is to show how the construct of social capital, which has emerged from sociology and which is accepted by economists and politicians as both a measure and tool of development, might offer South African public librarians a frame in which to measure and communicate their societal contributions.

\section{Social capital: a measure of and tool for socio-economic development}

The concept of social capital has emerged from common ground between social and economic theory. It is a term wellestablished in education, sociology, economics, organisational theory and politics to denote the relationships among individuals, groups and/or organisations that create a capacity to act for mutual benefit (Robinson et al 200I). Through investing in social networking, individuals secure benefits for themselves and their groups, which would not be possible otherwise. The term is used side by side with several others such as social exchange theory, social connectedness, civic engagement and community. Financial capital might reside in a bank and human capital in individuals' heads, but social 
capital resides in the structure of peoples' relationships. Social capital stocks have been found to be crucial in the alleviation of poverty and the sustaining of development (World Bank 2007).

Simply put, networks of relationships among persons, companies, institutions and civic organisations enable a society to function effectively. As Stiglitz suggests, if lack of social capital is a common characteristic of developing economies then "we should be as concerned about its progress as we are about increasing human and physical capital" (1999). If social capital is a factor in "making things happen" in a community (Dovey \& Onyx 200I: 152), then it makes sense to measure it and invest in it before any development project is undertaken.

Writers on social capital are firm that it is not a warm fuzzy concept. Rather it identifies specific benefits, both individual and group (Glaeser 200I), that come from social networks and describes them in economic terms. The essence of dictionary definitions of financial and physical capital is that the accumulation of wealth allows for the production of more wealth and assets are available for use in the production of further assets. Similarly, social capital can be accumulated over time, drawn on and converted into other forms. Social capital increases with use; but is reduced and destroyed through neglect (Emmett 2000: 508).

Whether social capital's implied analogy with financial or physical capital is wholly appropriate is debatable. It gives inherent value to threads in the social fabric such as building community, networks, and community activities so that the worth of these things is not lost under an economic rationalist world view. Social capital indicators thus offer an alternative measure of the well-being of a community and its potential for development. In his recent Nelson Mandela memorial speech, President Thabo Mbeki warns of the threat to social cohesion by the post-1994 individualistic accumulation of money and refers to social capital as an alternative value system (2006). Statistics New Zealand's framework for the measurement of social capital incorporates long-existing Maori concepts close to social capital (Robinson et al 200I: 12) and South Africans might likewise draw parallels between the concept of social capital and ubuntu, the indigenous South African equivalent (Jones, Nyland \& Pollitt 200I: 6; Piazza-Giorgi 2002: 633).

Where and why social capital originates is much debated. As Stambaugh points out, the construct of social capital suffers from the chicken-and-the-egg phenomenon (2002). For example, does trust among people lead to civic activity; or, do civic groups, once established, generate the trust? Jung's ethnographic account of an episode of collective action in Cape Town in 1995 illustrates this question (2003). She shows how the sudden occupation of an empty school by 500 youths, bussed in by student activists, unlocked social capital in a suburb which was characterised by "a complete absence of such norms, networks and trust as might comprise social capital" (p. I52). Under threat from the aimless students, the fragmented and divided community built solidarity and trust. After the episode, Jung, however, was unsure if the residue of social capital might engender more or if it would just dissipate.

Social capital acts as a community's capital resource in various ways (Robinson et al 200 I: II). It creates norms expected and trusted practices and behaviours. It vests authority in leaders which facilitates efficient decision taking and action. It allows for "appropriable" organisation in that the goals of one group might be taken over by another, temporarily or for the long term. Thus, expertise and other resources, including information, are shared. Groups are formed with the intention of gaining specific benefits for themselves but the larger community shares in the benefits. This kind of social networking creates a web of obligation, trust and reciprocity. People, who contribute in one area at one time, expect that their investment will be returned in the future, perhaps in quite a different area. Of specific interest to the subject of this article, the role of public libraries in social capital, is the pooling of information that social capital depends on.

Most current comment refers to Bourdieu's identification of two kinds of social connections: horizontal, which bond people with similar interests, and vertical, which serve as bridges between disparate groups. Horizontal bonds create a sense of community identity and common purpose; but they can bring what Putnam (2000: 350 ) calls the "dark side" of social capital - groupings who only work for their narrow self interest and whose attributes include intolerance, cronyism and corruption. Vertical ties transcend social and geographic divides - and are needed to gain access to resources. They allow what Emmett calls "parochial" groups to "scale-up" to become larger more powerful regional networks (2000: 515). Forums that cut across cultural, religious and socio-economic barriers are seen by funding agencies as conducive to economic prosperity and sustainable development. Alkalimat and Williams's case study of the role of social capital in establishing a community technology centre, whose mission is to counter the continuing social exclusion of African Americans, illustrates the pragmatic use of both bonding and more "lucrative" bridging social capital (200I).

Robert Putnam's groundbreaking work in Italy and the US in the 1990s established I4 indicators of social capital which he groups as follows:

- community organisational life: membership of clubs and associations

- engagement in civic affairs: voting and attending public meetings

- community volunteerism: numbers of non-profit-organisations in a community, volunteer work

SA Jnl Libs \& Info Sci 2007, 73(I) 
- informal sociability: amount of mixing with friends

- social trust: general feelings that most people can be trusted, leading to expectations that one's generosity will be reciprocated (2000).

Not all researchers use all six of Putnam's benchmarks of social capital. Campbell, Williams and Gilgen, for example, omit the measures of trust and sociability in their study of the relationship between social capital and HIV infection in a South African mining community (2002), preferring to focus on membership of community groups such as savings societies and sports clubs. Other research, such as Narayan and Pritchett's study in Tanzania (1999), focuses on trust, seeing it as a predictor of group membership and collective action. Whether volunteering is always a useful measure of positive social capital has been questioned. For example, Mirafatab's case study of the use of unpaid workers to replace paid waste collectors in Cape Town between 1997 and 200 I shows how officialdom might, by using catch phrases, such as "community-based participation" , "empowerment" and "social capital", in fact decrease levels of trust and inclusion (2004). And Witbooi's case study of an attempt to set up a community library in an impoverished community in Cape Town concludes that expecting people who are struggling to survive to work for nothing was "very idealistic and optimistic" (2006: 49).

The power of Putnam's work lies in his use of his indices to measure social capital across the US and then correlate social capital levels with accepted measures of community well-being and social inclusion, such as levels of education, crime rates, economic prosperity, employment rates, health and democratic citizenship (2000). Although Putnam is cautious about claiming linear causal relationships between the two sets of measures, he suggests that the evidence is strongly in favour of social capital. The focus of much of the recent research in social capital has been to test Putnam's claims in relation to specific measures of social quality, such as health, violence, crime rates, and family income - and/or in different environments.

The research broadly supports Putnam's conclusions. Stiglitz's study of a community in rural Uganda (1999) concludes that social capital is affected by and affects the developmental process but, as do Alkalimat \& Williams (200I), he warns that government initiatives can reduce social capital if they destroy long-existing community networks. Narayan and Pritchett's study in Tanzanian villages (1999) shows a causal link between social capital and both the provision of basic public services by government and poverty levels. The authors conclude that collective action by community groups is crucial to the generation and management of resources. Mallucio, Haddad and May's study in the South African province of KwaZulu Natal correlates data on household welfare with membership of formal and informal groups, which they see as a proxy measure of social capital. It finds that in 1993 group memberships had no clear returns for families; but, in postapartheid South Africa in 1998, active membership does affect positively family income and expenditures (2000: 76). Piazza-Giorgi's research in Soweto (200I) has similar findings and agrees on the need to distinguish between trust in different actors. Thus, both studies find a growth in membership in formal institutions at the expense of informal ties. Emmett's examination of "community participation" projects in South Africa suggests that fragmentation in poor communities and expectations of immediate and personal benefits hamper development. He concludes that the presence of bridging social capital explains why some community-based projects succeed and others fail (2000: 509).

The relevance to South African society is clear. Apartheid eroded social capital in contradictory ways. It reinforced traditional hierarchical structures; at the same time, its forced removals and migrant labour systems destroyed communities' social capital (Emmett 2000: 510; Haddad \& Maluccio 2003: 578). As Emmett points out, Mamphele Rampheles's 199| "prophetic" list of symptoms of social disintegration, have all come true:

- high levels of family breakdown

- breakdown of discipline in families and schools

- high unemployment

- high alcohol and drug abuse,

- high crime rates and endemic violence,

- the flight of skills and positive role models from the townships (Emmett 2000: 510 ).

The linkages between social capital on one hand and social inclusion and socio-economic development on the other explain perhaps the South African government's interest in social capital. Much of the research in social capital concludes that the success of government development projects depends on the strength of ties in the community and its levels of trust. President Thabo Mbeki's reference to social capital in his Nelson Mandela memorial speech in 2006 has already been mentioned. The Western Cape Government's flagship developmental initiative, iKapa Elihlumayao (Growing the Cape), places social capital in its top two strategies in the "developmental state", thus: "human resources development including social (our value system) and human capital (our abilities)"; then, secondly, "social capital formation" (Brown 2004). The South African Deputy Minister for Provincial and Local Government's words connecting social capital and 
human capital to development in a speech in 2004 are of interest to public librarians, who work within local government structures:

In tandem with the development of human capital is the development of social capital. Local Government should therefore encourage and develop the presence and capacity of all relevant collective stakeholders in the local economy, for example, chambers of commerce, co-operatives, NGOs, CBOs, development agencies, etc.... (Hangana, 2004).

Whether or not the Deputy Minister includes a public library as one of the "development agencies" she refers to, her words would resonate with those who argue for the model of the developmental public library.

\section{Public libraries and social capital}

The close links of social capital to education and the role of both in socio-economic development explain its significance for the public library. Glaeser (200I: 390 ) points out that the most robust correlate of social capital across individuals in all countries researched is years of schooling. The reason, he claims, is that schools teach social skills. In response perhaps to this kind of research, the South African Western Cape Education Department's recent vision document describes education as a powerful agent in a community's "social and human capital" so that it builds its capacity to take informed decisions and to participate actively in existing social and economic institutions (Western Cape Education Department 2005: 23).

Education and socio-economic development are both central to the mission of the developmental public library, as mentioned earlier. The argument of this article is that, in three overlapping ways, public libraries are agents for social capital:

- their role in education, both formal and informal

- their role as community information services and in information literacy education, which Dudley calls "community informacy" (2000: 31)

- their part in social cohesion. If public libraries are indeed "community libraries" as the professional literature claims, then social capital is very much their business.

Despite these arguments, which might well be self -evident to librarians, public libraries just do not feature in the social capital literature, not even as indicators of community organisational life. The neglect of public libraries in Putnam's huge project on the rise of and erosion of social capital in American society, discussed in the preceding section, has led to much soul searching in public library circles in America and throughout the world. Librarians, it seems, have failed in answering and communicating what Durrance (2003) calls the basic question of what differences they make to a community. In describing Putnam's appearance at an American Library Association's meeting after his book's publication, Preer claims that, although he acknowledged the role of public libraries in active citizenship he, once again, missed the point that public libraries "embody" the concept of social capital. Her frustration is clear in her words:

But while Putnam chronicles civic activity and social connection in everything from churches to Moose lodges to reading groups and bowling leagues, he almost totally ignores the role of libraries in creating social capital (2001: 60).

Preer quotes from documents from the late $19^{\text {th }}$ century to show that American public librarians have always been aware of their positive role in building social capital - even if they did not use that term. Since the 1930s, the American Library Association has campaigned for federal funds to demonstrate the value of libraries in underserved areas. The puzzle is how, in spite of the advocacy over so many years, public libraries remain so invisible in the literature of social capital.

Responding to the challenge, librarians have argued that libraries do more than depend on social capital - they are agents in the building of social capital. Preer analyses this role as follows:

- Public libraries create an informed citizenry, though their provision of information - on their shelves and through organising meetings on community issues.

- They create communities - through both binding and bridging social capital. Branch libraries respond to the uniqueness of communities; while their library networks facilitate bridging activities. Libraries support the organisations in their community; their collections and educational and cultural programmes reflect the cultures and groupings within their communities.

- Libraries are free; they are open to all and to all ideas. They promote tolerance and open-mindedness.

- Library users are a "communications elite", active in their communities.

- States with high levels of social capital have the best libraries - evidenced by comparing social capital indexes with Hennen's ranking of American public libraries (2002).

According to Durrance (2003: 54I), Putnam is only one of many influential individuals or organisations who, over the decades, have lacked awareness of the existing and potential impact of libraries. Highly relevant to South Africa is the comment that local government tends to see libraries primarily as cost centres and still sees them as middle-class

SA Jnl Libs \& Info Sci 2007, 73(I) 
institutions (Bundy 2003; Hillenbrand 2005). In a climate of public service accountability, librarians now recognise the need to find measures of outcome that people outside the field will understand. In economic terms, the aim is to prove that public libraries provide a good return on investment. An example is the study by the University of South Carolina (Barron et al 2005) of the economic impact of public libraries in South Carolina, which found that for every $\$ 1$ spent by state and local government on public libraries the direct and indirect return on investment is $\$ 4.48-$ a return of $350 \%$.

Stambaugh's Masters Degree research project (2002) is a rare example of an attempt to document the correlations between social capital and public libraries. She used the Saguaro Seminar benchmarks (Saguaro Seminar: Civic Engagement in America 2002) to identify communities in the United States with high and low social capital and then randomly selected public libraries from each group. For each library she collected data on their location, nongovernmental funding, volunteering, salaries, kinds and numbers of programmes, and their target groups in order to identify specific factors that correlate with social capital levels in the community. Stambuagh acknowledges that her study cannot make conclusive findings on causal links between specific public library factors and social capital. However, she does find evidence of correlations between specific library programmes, such as information literacy interventions and literature courses, and the forging of bonding and bridging relationships. She suggests that smaller scale case studies might be a more effective methodology.

Hillenbrand provides such a study in her investigation of how one Australian library, the Mount Barker Community Library in Adelaide, contributes to social capital (2005). Her purpose is to demonstrate the role of the library in the strategic goals of the Mount Barker Council, namely "to create successful communities", and in the State's goal to make South Australia a place where "people care for each other and contribute to their communities". Social inclusion, the wish to make the library a "place for all", is identified in its mission documents as one of the four strategic drivers of the library - the others being information literacy, staff development and community partnerships. As she points out, all four relate to social capital. Some of her key findings include:

- the diversity of library users of whom $59 \%$ live outside the library's town

- the continued need for the library's core services - reading resources and information

- some changes in purpose: $45 \%$ of her respondents come to the library to use its computers

- the importance of the library as a place and of its equity of access. It is "somewhere to go"; it is "safe"; teenagers use it as a place to meet friends; $81 \%$ of respondents report that they talk to at least one other person in the library

- the role of the library's information and computer literacy programmes for youth and older people in community capacity building.

Hillenbrand makes clear the impact of the new library manager's emphasis on the library as a "community centre" whose mission is to nurture social inclusion. Perhaps a pointed message for the library profession is her comment on the benefits of the manager's not being a qualified librarian. The library's youth and information officer, who, Hillenbrand stresses, is a professional social worker, has built bridging social capital for the library by working with several community youth groups.

\section{South African public libraries and social capital}

Given the deteriorating position of public libraries in South Africa and the uncertainty over their governance and funding that were described in an earlier section in this article, the international trends towards identifying the economic and social value of libraries must resonate with South African public librarianship. And indeed, two projects, funded by the Carnegie Corporation and the Print Industries Cluster Council, provide evidence of new awareness of the need to gather empirical evidence of the value of South African public libraries. Between 2000 and 2004, the Public \& Community Libraries Inventory of South African (PaCLISA) project attempted to build a comprehensive inventory of South African public libraries (Van Helden \& Lor 2002). Then the Print Industries Cluster Council undertook another survey to find performance benchmarks for public libraries (de Jager \& Nassimbeni 2005). However, neither study was entirely successful, as public library staff struggled to complete the too complex questionnaire (Lor, Van Helden \& Bothma 2005). The Department of Arts and Culture recently initiated a third project, which aims at establishing benchmarks for a transformed public library service (Dominy 2006).

It is difficult to find empirical evidence of the role of South African public libraries in social capital, although the themes of LIASA's annual conferences clearly advocate the role of libraries in community building. These include: "Libraries: partners in learning, nation building and development" in 2006, "Taking libraries to the people" in 2005, and "Libraries and democracy: the vital link" in 2004. However, a fundamental flaw in public librarians' rhetoric is the prevailing low membership of their libraries. Across the country, less than $10 \%$ of South Africans belong to a public library - compared with $48 \%$ in Australia (Bundy 2003). It is hard to make claims about public libraries as agents of social capital when they serve only a tiny minority of the population. The uneven distribution of libraries is of course a contributing factor. The

SA JnI Libs \& Info Sci 2007, 73(I) 
Director of Mpumalanga's provincial library service estimates, for example, that his rural province needs another 98 public libraries if it is to meet UNESCO guidelines on access (Le Roux \& Hendrikz 2003).

Moreover, the author's research suggests that unavailability is not the only problem. Her survey of Mpaumalanga libraries in 2004 (Hart 2006a; 2006b) shows that township libraries are heavily used by school learners in the afternoons but adults hardly enter them in their quiet mornings. Le Roux (2001: 194) attributes the prevailing under-use to perceptions that the library is for an elite middleclass. In his recent conceptual article on the role of public libraries in good governance (2006), Arko-Cobbah suggests that South African public libraries need to change their image if they wish to extend their services to previously excluded group. It seems that research is urgently needed in how South Africans perceive public libraries.

Witbooi's account of a failed attempt to set up a community/school library in a newly built township in Cape Town gives a rare insight into such perceptions and exemplifies the risk in post 1994 South Africa of too glib assumptions about what she calls an "African" library model (2006). Despite months of preparatory work, the library did not open owing to, it seems, inadequate stocks of trust to sustain the community project beyond early enthusiasm. The case study serves to illustrate many of the points made in the social capital research literature. Only on reflecting on the lessons of the project does Witbooi turn to the concept of social capital in acknowledging that its stocks should have been assessed before the project began. The "chicken and egg" question, referred to earlier, is evident in that the failure was due to the low reserves of social capital in the newly established community; yet, one of the aims of the project was to generate a sense of belonging and community. All in all, the case study offers a tantalising glimpse of how the library might have built social and human capital.

Witbooi attributes the ultimate failure of the project to its unrealistic reliance on volunteers - no professional staff being allocated to the library either by the school system or the local government library authority. And there is evidence that the biggest challenge for new vision-building is the inadequate staffing of South African public libraries - in terms of numbers and quality. The author's 2004 study in Mpumalanga (Hart 2005) found that only $30 \%$ of staff in charge of public libraries have post school education, usually a degree or diploma in librarianship. Twenty-three of the 57 respondents run small rural or township one-person libraries. Of the 23 , only three have post school education - and five lack school leaving matric. These five were promoted from cleaning posts having being deemed to "know it all" after their years of working in the library. The study also reveals a trend to ad-hoc secondments from municipality offices. Local authorities, apparently, have little respect for professional library education.

The issue of professional education is not confined to South African public librarianship. In examining the "crisis" of "disorganized and unproductive" rural libraries in the United States, Luchs (200I: 5I) contends that the prevailing low level of professional education of their staff is their biggest weakness. While acknowledging that the American rural librarians in their studies are dedicated and enthusiastic, both Luchs (200I) and Vavrek (1997) believe that the diverse information needs of their communities demand professionally qualified staff. Luchs's answer to claims that the undereducated staff in her study might be perfectly adequate is that they "simply do not know any better" (200I: 53). Their rural communities, she contends, moreover, may not realise that their library services are inadequate because they have nothing to compare them with. Bundy's warning (2003) that the lack of professional staff in rural Australian libraries hinders leadership and vision is germane to the theme of this article.

Hillenbrand's study of social capital in an Australian public library, which was described in the previous section, demonstrates the importance of ties with other community groups. The author's survey of Mpumalanga libraries suggests, however, that South African public libraries' ties with other community organisations are rather weak. Figure I summarises responses from the 57 respondents to the question on connections with other organisations in the community.

The most common category of partnership is business - a closer look at the responses showing that they all refer to the financial support given to public libraries in Mpumalanga by SAPPI, SASOL and Eskom, three large corporations.

In a country with high levels of adult illiteracy, the absence of any mention of connections to adult literacy groups is surprising and throws doubt on any expectation that South African public libraries might be active in literacy education. Support for this doubt is provided by other recent research that finds that only $23 \%$ of libraries play a role in adult basic education (Nassimbeni \& May 2006: 19). The study reveals, moreover, large variations in the kind of involvement, with some of the $23 \%$ merely offering a venue for literacy education and others directly involved in the programme. The value of the study is that it provides examples of good practice and insight into the favourable conditions that encourage such community work. Perhaps South African librarians need to heed Stambaugh's suggestion that the best way to document the social role of public libraries is through case study research. 


\section{Objectives}

The study's objectives include the following:

I.To examine the location of the libraries' websites in the university website.

2. To measure each library's link performance in terms of web page, directory, domain and site out-links and in-links.

3.To examine each library's performance in terms of the provision of essential online services (e.g. webcatalog, web forms, web search engines, etc).

4. To map the libraries' inter-linkages with each other.

5. To find out the most targeted web-sites/pages.

\section{Literature review}

Historically, the Internet and Web are relatively new concepts, but they have elicited a lot of excitement and interest from several scholars as illustrated in the enormous literature that discusses their features, opportunities, challenges and impact, among other issues. Attempts have been made to develop indicators that can be used to measure research and evaluate the performance of individuals, institutions, and countries in the Internet, as a whole and more particularly, on the Web. Virtually all disciplines, including library and information science (LIS), have utilized these Internet-related studies. Specifically, the Internet's (including Web's) impact on libraries and the usage of the Internet-related services by libraries have received attention from several researchers based in various countries and from a variety of disciplines, including LIS

Henry (1996) provides a description of WebCATS - a directory of online public access catalogs that offers access to OPACs which have Web interfaces. A similar description is offered by Kochtanek, Hein \& Kassim (200I) concerning what the authors call 'Projec DL'. The project was meant to create a site that can assist users to access digital library collections as well as information resources related to the study of digital libraries. McCready's (1997) study offers a variety of hints on creating a 'library-related' website. The study focused on the need for a library website, the personnel to develop the website, evaluating its usage, and organizing and structuring it. Westman (200I), too, provides librarians with resources (i.e. database-backed web pages) that they can use for effective construction of library websites. Falk (1999) argues that a library webpage is supposed to serve two purposes, namely provide a means to users to access remotely available information from the library while serving as a patron's guide to the library's collections, and also as a gateway to the resources of the Web. Saeed, Asghar, Anwar \& Ramzan (2000) sought to survey the use of the Internet in university libraries of Pakistan. The authors found that university libraries in Pakistan use the Internet for reference work, classification and cataloguing, document delivery services, and subscription to online journals, etc. On their part, the Arabian Gulf libraries use the Internet to offer such services as web catalogs, web forms, orientation and training and web search engines (Ahmed, 2002). Arte (2001:93) studied the role of the research library website in the management of the scientific information environment and argues that "each library can develop an individualized change management program that takes into consideration the basic elements of experienced staff, new staff, and creative supervisory practices". Several studies have been carried out in order to introduce main ideas and concepts underlying web services, and resources and opportunities that the Internet offer libraries and librarians (e.g. Cordeiro \& de Carvalho, 2002; Hundie, 2003); and library website maintenance (Kennedy, 2004).

There are several indicators or criteria that can be used to evaluate libraries' websites for quality, some of which include design and structure; quality of information; links and navigation; aesthetic impression; miscellaneous; and general assessment (Clausen, 1999). According to Clausen (1999:83), "one of the most serious and widespread objections against information found on the World Wide Web is that the quality in many cases is doubtful". Using the aforementioned criteria for evaluating Danish academic libraries, the author noted that the libraries' websites were above average when compared with other web sites in general. However, they did not measure up to expectations as "virtual expressions of the quality levels of the libraries" (Clausen 1999:83). On her part, Xue (2004) used user statistics to assess the Government Publications Library at the University of Colorado, Colorado, USA. She examined the library website's organization (including access, searchability, and structure) of electronic government information in subject category format and noted, among other issues, that the website attracted a large volume of traffic due to its comprehensive coverage of federal and state government, foreign country and international organizations; detailed classification of subjects; and detailed annotation for each link. She concludes that usage statistics are useful monitoring search engine ranking, improving display, structure and searchability. Pacios (2003) sought to examine management-related documents posted on the Spanish libraries' websites and in view of that the author analyzed the structure and contents of the web pages, among other aspects. Pacios (2003:536) observed that the "information is scanty in many cases - often resulting from a lack of a suitable information policy for determining what is published on the Web - although libraries are beginning to evaluate the quality of their services". 
It is notable from this brief review of the literature that little has been achieved in evaluating libraries using link analysis. Link analysis is a measure of the quality of and relevance of the set of links pointing to a given site (www.2020visible.com/re-terminology.html). This analysis is meant to assist in determining websites that do promote a given website and how popular one's website is. Link popularity measures how many other sites indexed in the same search engine have links to one's site by count of links to that particular site. This method has been used to measure the universities' web impact factors (Thelwall, 2002a); find the most important university web pages (Thelwall, 2003); identify link relationships between universities (Thelwall, 2002b; 2002c); classify link types in academic environments on the Web (Bar-llan, 2005); and to rank universities (InterLab, 2005).

\section{Methods and tools}

The following procedures were used to identify academic libraries whose websites were the subject of the current study:

I.Selection of countries: At this stage, a total of six countries, out of a total of 18 countries (excluding islands) in eastern and southern Africa, were purposefully selected for study as follows: Kenya, Tanzania and Uganda (Eastern Africa) and Botswana, South Africa and Zimbabwe (Southern Africa), i.e. three each from eastern and southern Africa.

2.Selection of universities: universities in each of the six countries were identified using several sources that included:

- Catalogue of world universities (http://www.webometrics.info/university_by_country_select.asp.htm)

- Canada's University and College Information Center (http://www.canadian-universities.net/index.html)

- International Network for Higher Education in Africa (2003) (http://www.bc.edu/bc_org/arp/soe/cihe/inhea/index.htm)

- Study in South Africa (http://www.studysa.co.za/index.php)

A total of 59 universities which had own websites were identified from among a total of 65 universities in the six countries.

3.Selection of libraries: It was intended that all academic libraries in the six selected countries be surveyed. As a result, each of the university's website was browsed for information regarding the library's home page URL address. This address was important because it was the one that was used to measure the libraries' performance on the Web. Upon browsing the universities' websites for libraries' URL addresses, only 36 libraries were selected for study based on home page ownership. Excluded from analysis were academic libraries

a) whose URL home page addresses were so long and contained punctuation marks, (e.g. http:// www.unisa.ac.za/Default.asp?Cmd=ViewContent\&ContentID = I7)

b) whose home pages were still under construction.

A complete list of the academic libraries in the six countries is provided in Table I. The last column provides notes on the reasons for exclusion of some of the libraries from the final analysis.

Relevant data were extracted from the Internet between $5^{\text {th }}$ and $20^{\text {th }}$ July 2006 by crawling the web using the SOCSCIBOT computer software (developed by Prof. Mike Thelwall). The extraction of data was conducted only once for each library in an exercise that was so slow and sometimes took as long as three days (day and night) in the case of some libraries, especially those that had large websites. Data were analyzed using the SOCSCIBOT toolkit that consists of matrix and pajek tools in order to:

I. find out the volume of each library's total web pages

2.find out the volume of each library's total out-links

3.measure each library's in-links from and out-links to other libraries in the six countries

4.measure each countries total library web pages and out-links

5.calculate the average number of web pages and out-links per library in each country

6.rank libraries according to the number of pages, out-links and out-links per page.

The Pajek computer software was used to prepare the visual networks. 
Table I Countries, universities and libraries selected for study

\begin{tabular}{|c|c|c|c|}
\hline UNIVERSITY & COUNTRY & LIBRARY HOME PAGE & NOTES \\
\hline Botswana Collge of Agriculture [BCA] & Botswana & & $\begin{array}{l}\text { Under construction } \\
\text { (Excluded) }\end{array}$ \\
\hline University of Botswana [BU] & Botswana & http://www.ub.bw/library/ & \\
\hline Africa Nazarene University [ANU] & Kenya & http://www.anu.ac.ke/library/default.html & \\
\hline $\begin{array}{l}\text { The Catholic Univ. of Eastern Africa } \\
\text { [CUEA] }\end{array}$ & Kenya & http://www.cuea.edu/library/lib.htm & \\
\hline Daystar University [DU] & Kenya & & $\begin{array}{l}\text { No library website } \\
\text { (Excluded) }\end{array}$ \\
\hline Egerton University [EU] & Kenya & http://www.egerton.ac.ke/academics/library/index.php & \\
\hline Maseno University [MASENO] & Kenya & http://www.maseno.ac.ke/library/ & \\
\hline Moi University [MU] & Kenya & http://www.mu.ac.ke/library/index.html & $\begin{array}{l}\text { Under construction } \\
\text { (Excluded) }\end{array}$ \\
\hline $\begin{array}{l}\text { University of Eastern Africa, Baraton } \\
\text { [UEAB] }\end{array}$ & Kenya & http://www.ueab.ac.ke/library/ & \\
\hline University of Nairobi [UONBI] & Kenya & http://library.uonbi.ac.ke/ & \\
\hline $\begin{array}{l}\text { United States International University } \\
\text { [USIU] }\end{array}$ & Kenya & http://www.usiu.ac.ke/library/index.htm & \\
\hline $\begin{array}{l}\text { Jomo Kenyatta Univ. of Agri. \& Tech. } \\
\text { [JKUAT] }\end{array}$ & Kenya & & $\begin{array}{l}\text { No library website } \\
\text { (Excluded) }\end{array}$ \\
\hline Kabarak University [KABARK] & Kenya & http://www.kabarak.ac.ke/library/index.htm & \\
\hline Kenya Methodist University [KEMU] & Kenya & & $\begin{array}{l}\text { No library website } \\
\text { (Excluded) }\end{array}$ \\
\hline $\begin{array}{l}\text { Kiriri Women's Univ of Sci\&Tech } \\
\text { [KWUST] }\end{array}$ & Kenya & & $\begin{array}{l}\text { Under construction } \\
\text { (Excluded) }\end{array}$ \\
\hline $\begin{array}{l}\text { Strathmore University } \\
\text { [STRATHMORE] }\end{array}$ & Kenya & http://www.strathmore.edu/academics/library.html & \\
\hline Cape Peninsula Univ of Tech [CPUT] & South Africa & http://www.cput.ac.za/library/ & \\
\hline $\begin{array}{l}\text { Central Univ of Technology. Free State } \\
{[\text { CUT] }}\end{array}$ & South Africa & http://www.cut.ac.za/web/academics/library/homepage & \\
\hline Durban Institute of Technology [DUT] & South Africa & http://library.dit.ac.za/index.html & \\
\hline $\begin{array}{l}\text { Nelson Mandela Metropolitan Univ } \\
\text { [NMMU] }\end{array}$ & South Africa & http://www.nmmu.ac.za/default.asp?id=2330\&bhcp $=I$ & $\begin{array}{l}\text { Un-crawlable address } \\
\text { (Excluded) }\end{array}$ \\
\hline Rhodes University [RU] & South Africa & http://www.ru.ac.za/library/ & \\
\hline Stellenbosch University [SUN] & South Africa & http://www.sun.ac.za/library/ & \\
\hline $\begin{array}{l}\text { Tshwane University of Technology } \\
\text { [TUT] }\end{array}$ & South Africa & http://lib.tut.ac.za/ & \\
\hline $\begin{array}{l}\text { Univ of KwaZulu Natal [UKZN - } \\
\text { WEST] }\end{array}$ & South Africa & http://www.ukzn.ac.za/westvillelibrary/ & \\
\hline $\begin{array}{l}\text { Univ of KwaZulu Natal [UKZN - } \\
\text { HOWARD] }\end{array}$ & South Africa & http://www.library.und.ac.za & Used www.library.und.ac.za \\
\hline $\begin{array}{l}\text { Univ of KwaZulu Natal [UKZN - } \\
\text { HOWARD] }\end{array}$ & South Africa & http://www.library.und.ac.za/med/medical.htm & Used www.library.und.ac.za \\
\hline $\begin{array}{l}\text { Univ of KwaZulu Natal [UKZN - } \\
\text { HOWARD] }\end{array}$ & South Africa & http://www.library.unp.ac.za/ & Used www.library.und.ac.za \\
\hline University of Cape Town [UCT] & South Africa & http://www.lib.uct.ac.za & \\
\hline University of Fort Hare [UFH] & South Africa & http://www.ufh.ac.za/library/index.html & \\
\hline University of Johannesburg [U]] & South Africa & http://www.uj.ac.za/library & \\
\hline $\begin{array}{l}\text { University of Limpopo (North) } \\
\text { [UNORTH] }\end{array}$ & South Africa & http://www.unorth.ac.za/Library/index.html & \\
\hline University of Pretoria [UP] & South Africa & http://www.ais.up.ac.za/ & \\
\hline University of South Africa [UNISA] & South Africa & $\begin{array}{l}\text { http://www.unisa.ac.za/ } \\
\text { Default.asp?CInd =ViewContent\&Content ID }=17\end{array}$ & $\begin{array}{l}\text { Un-crawlable address } \\
\text { (Excluded) }\end{array}$ \\
\hline University of the Free State [UOVS] & South Africa & http://www.uovs.ac.za/faculties/index.php?FCode $=12$ & $\begin{array}{l}\text { Un-crawlable address } \\
\text { (Excluded) }\end{array}$ \\
\hline University of the North [UNORTH] & South Africa & http://www.unorth.ac.za/Library/index.html & \\
\hline
\end{tabular}




\begin{tabular}{|c|c|c|c|}
\hline $\begin{array}{l}\text { University of the Western Cape } \\
\text { [UWC] }\end{array}$ & South Africa & http://www.uwc.ac.za/library/ & \\
\hline University of Venda [UNIVEN] & South Africa & http://www.univen.ac.za/library/library.php & \\
\hline University of Witwatersrand [WITS] & South Africa & http://www.wits.ac.za/library/index.htm & \\
\hline Vaal University of Technology [VUT] & South Africa & http://www.vut.ac.za/metadot/index.pl?id=2860 & $\begin{array}{l}\text { Un-clawlable address } \\
\text { (Excluded) }\end{array}$ \\
\hline Walter Sisulu University [WSU] & South Africa & http://www.wsu.ac.za/library/mainlibrary.htm & \\
\hline $\begin{array}{l}\text { Dar es Salaam Institute of Technology } \\
\text { [DIT] }\end{array}$ & Tanzania & & $\begin{array}{l}\text { University site couldn't be } \\
\text { accessed (Excluded) }\end{array}$ \\
\hline Dar es Salaam University [UDSM] & Tanzania & http://www.udsm.ac.tz/library/index.htm & \\
\hline $\begin{array}{l}\text { Hubert Kairuki Memorial University } \\
\text { [HKMU] }\end{array}$ & Tanzania & & $\begin{array}{l}\text { No library website } \\
\text { (Excluded) }\end{array}$ \\
\hline International Med. \& Tech Univ [IMTU] & Tanzania & & $\begin{array}{l}\text { No library website } \\
\text { (Excluded) }\end{array}$ \\
\hline Mount Meru University [MMU] & Tanzania & & $\begin{array}{l}\text { No Library website } \\
\text { (Excluded) }\end{array}$ \\
\hline Mzumbe University [MZUMBE] & Tanzania & http://www.mzumbe.ac.tz/libary.htm & \\
\hline $\begin{array}{l}\text { Sokoine University of Agriculture } \\
\text { [SUANET] }\end{array}$ & Tanzania & http://snalwww.suanet.ac.tz/index.html & \\
\hline Bugema University [BUGEMA] & Uganda & & $\begin{array}{l}\text { University site couldn't be } \\
\text { accessed (Excluded) }\end{array}$ \\
\hline Central Bugema University [CBU] & Uganda & & $\begin{array}{l}\text { No Library website } \\
\text { (Excluded) }\end{array}$ \\
\hline Islamic University in Uganda [IUU] & Uganda & & $\begin{array}{l}\text { No Library website } \\
\text { (Excluded) }\end{array}$ \\
\hline Kampala International University [KIU] & Uganda & $\begin{array}{l}\text { http://www.kiu.ac.ug/ } \\
\text { index.php?option=com_content\&task=blogcategory\&id=79\&/t } \\
\text { emid=56\&lang=en }\end{array}$ & $\begin{array}{l}\text { Un-crawlable address } \\
\text { (Excluded) }\end{array}$ \\
\hline Makerere University [MAKERERE] & Uganda & http://www.makerere.ac.ug/mulib/ & \\
\hline $\begin{array}{l}\text { Mbarara University of Sci. \& Tech } \\
\text { [MBARARA] }\end{array}$ & Uganda & $\begin{array}{l}\text { http://www.must.ac.ug/ } \\
\text { index.php?option = content\&task=view\&id=20\&ltemid }=34\end{array}$ & $\begin{array}{l}\text { Un-crawlable address } \\
\text { (Excluded) }\end{array}$ \\
\hline Africa University [AFRICAU] & Zimbabwe & http://www.africau.edu/Library/index.htm & \\
\hline Chinhoyi University [CHINHOVI] & Zimbabwe & http://www.cut.ac.zw/library/home.html & \\
\hline Midlands State University [MSU] & Zimbabwe & http://www.msu.ac.zw/libraries/index.php & \\
\hline $\begin{array}{l}\text { National University of Sci. \& Techn. } \\
\text { [NUST] }\end{array}$ & Zimbabwe & http://www.nust.ac.zw/library/index.htm & \\
\hline Solusi University [SOLUSI] & Zimbabwe & & $\begin{array}{l}\text { No library website } \\
\text { (Excluded) }\end{array}$ \\
\hline University of Zimbabwe [UZ] & Zimbabwe & http://www.uz.ac.zw/library/ & \\
\hline
\end{tabular}

\section{Results}

This section presents results and covers the following main areas of study: location of the library(ies) link on university website(s); essential web-based services offered by each library service; number of pages and out-links; distribution of library web pages and out-links by country; most commonly targeted web pages and Top Level Domains (TLDs); number of in- and out-links among the libraries; and the libraries' networks

6.1 Location of library links on the universities' websites

The location of a library link on the university's home page was evaluated so as to assess the ease of accessibility of the library's website. It was noted that out of the total 36 library websites surveyed, 34 (94.4\%) library links were provided on the respective university home pages. Only two (5.6\%) library websites had accessibility through the academic programs' directory.

\subsection{Essential web-based online services}

Libraries' websites were compared using four essential services, i.e. the provision of search engines, web-based Online Public Access Catalogs (OPACs), Web-based forms (e.g. feedback forms, etc) and library guides (including training and orientation resources) as shown in Table 2. It was observed that 12 (33.3\%) libraries provided search engine options on their websites while the $29(80.6 \%)$ libraries offered clients with the OPAC. There were six libraries that provided web 
forms while majority of the libraries (30 or $83.3 \%$ ) posted special library guides (orientation and training resources) on their websites.

\subsection{Number of pages and out-links}

Table 3 provides the rank distribution of the libraries according to the total number of web pages, out-links and out-links per page. There were a total of 22508 web pages and 275775 out-links, a situation that generated an average of I2.2523 out-links per page. Dividing the total number of pages and out-links by the total number of libraries yielded 625.2 web pages and 7660.4 out-links per library. On overall, the RU library is ranked number one with 628 pages, 19694 out-links and 31.3599 out-links per page followed by [all in the order of pages, out-links and out-links per page] CPUT library ( 335 , 9774, 29.1761), SUN library (917, 16784, 18.3032), UKZN - Howard College Campus library (218, 9578, 43.9358), and the UCT libraries (16468, 1736I6, 10.5426). Ranking number one according to the total number of pages was the UCT library followed by UP, SUN, UFH, and RU libraries in that order while the top ranking libraries in terms of the total number of out-links were UCT, RU, SUN, UP, and CPUT. The UKZN - HOWARD libraries topped the list of the libraries with the most out-links per page (i.e. 43.9358) followed by RU library (31.3599), CPUT library (29.176I), UKZN Westville library (25.8125) and Strathmore library (23.0000), etc.

Table 2 Provision of web-based essential services

\begin{tabular}{|c|c|c|c|c|c|}
\hline No. & Library website & Search Engine & OPAC & Web forms & Library guides \\
\hline I & www.ru.ac.za/library & $\checkmark$ & $\checkmark$ & $\checkmark$ & $\checkmark$ \\
\hline 2 & www.ais.up.ac.za & $\checkmark$ & $\checkmark$ & $\checkmark$ & $\checkmark$ \\
\hline 3 & www.cut.ac.za/web/academics/library & $\checkmark$ & $\checkmark$ & $\checkmark$ & $\checkmark$ \\
\hline 4 & www.ufh.ac.za/library & $\checkmark$ & $\checkmark$ & $\checkmark$ & $\checkmark$ \\
\hline 5 & www.wits.ac.za/library & $\checkmark$ & $\checkmark$ & $\checkmark$ & $\checkmark$ \\
\hline 6 & www.makerere.ac.ug/mulib & $\checkmark$ & $\checkmark$ & $x$ & $\checkmark$ \\
\hline 7 & http://snalwww.suanet.ac.tz & $\checkmark$ & $\checkmark$ & $x$ & $\checkmark$ \\
\hline 8 & www.msu.ac.zw/libraries & $\checkmark$ & $\checkmark$ & $x$ & $\checkmark$ \\
\hline 9 & http://library.dit.ac.za & $\checkmark$ & $\checkmark$ & $x$ & $\checkmark$ \\
\hline 10 & www.uj.ac.za/library & $\checkmark$ & $\checkmark$ & $x$ & $\checkmark$ \\
\hline 11 & www.uz.ac.zw/library & $\checkmark$ & $\checkmark$ & $x$ & $\checkmark$ \\
\hline 12 & www.ueab.ac.ke/library & $x$ & $\checkmark$ & $\checkmark$ & $\checkmark$ \\
\hline 13 & www.cput.ac.za/library & $x$ & $\checkmark$ & $x$ & $\checkmark$ \\
\hline 14 & www.sun.ac.za/library & $x$ & $\checkmark$ & $x$ & $\checkmark$ \\
\hline 15 & www.library.und.ac.za & $x$ & $\checkmark$ & $x$ & $\checkmark$ \\
\hline 16 & www.lib.uct.ac.za & $x$ & $\checkmark$ & $x$ & $\checkmark$ \\
\hline 17 & www.uwc.ac.za/library & $x$ & $\checkmark$ & $x$ & $\checkmark$ \\
\hline 18 & www.ub.bw/library & $x$ & $\checkmark$ & $x$ & $\checkmark$ \\
\hline 19 & www.ukzn.ac.za/westvillelibrary & $x$ & $\checkmark$ & $x$ & $\checkmark$ \\
\hline 20 & http://lib.tut.ac.za & $x$ & $\checkmark$ & $x$ & $\checkmark$ \\
\hline 21 & www.cut.ac.zw/library & $x$ & $\checkmark$ & $x$ & $\checkmark$ \\
\hline 22 & http://library.uonbi.ac.ke/website & $x$ & $\checkmark$ & $x$ & $\checkmark$ \\
\hline 23 & www.usiu.ac.ke/library & $x$ & $\checkmark$ & $x$ & $\checkmark$ \\
\hline 24 & www.anu.ac.ke/library & $\checkmark$ & $x$ & $x$ & $\checkmark$ \\
\hline 25 & www.nust.ac.zw/library & $x$ & $\checkmark$ & $x$ & $\checkmark$ \\
\hline 26 & www.univen.ac.za/library & $x$ & $\checkmark$ & $x$ & $\checkmark$ \\
\hline 27 & www.udsm.ac.tz/library & $x$ & $\checkmark$ & $x$ & $\checkmark$ \\
\hline 28 & www.unorth.ac.za/library & $x$ & $\checkmark$ & $x$ & $\checkmark$ \\
\hline 29 & www.africau.edu/Library & $x$ & $\checkmark$ & $x$ & $\checkmark$ \\
\hline 30 & www.kabarak.ac.ke/library & $x$ & $x$ & $x$ & $\checkmark$ \\
\hline 31 & www.maseno.ac.ke/library & $x$ & $x$ & $x$ & $x$ \\
\hline 32 & www.egerton.ac.ke/academics/library & $x$ & $x$ & $x$ & $x$ \\
\hline
\end{tabular}

SA Jnl Libs \& Info Sci 2007, 73(I) 


\begin{tabular}{|c|c|c|c|c|c|}
\hline 33 & www.strathmore.edu/academics & $x$ & $x$ & $x$ & $x$ \\
\hline 34 & www.wsu.ac.za/library & $x$ & $x$ & $x$ & $x$ \\
\hline 35 & www.cuea.edu/library & $x$ & $x$ & $x$ & $x$ \\
\hline 36 & www.mzumbe.ac.tz/library & $x$ & $x$ & $x$ & $\mathrm{x}$ \\
\hline
\end{tabular}

Key: $\checkmark=$ Service available; $x=$ Service not available

Table 3 Number of pages and out-links

\begin{tabular}{|c|c|c|c|c|c|c|c|c|}
\hline \multirow[b]{2}{*}{ No } & \multirow[b]{2}{*}{ Overall rank } & \multirow[b]{2}{*}{ Site } & \multicolumn{2}{|c|}{ Pages } & \multicolumn{2}{|c|}{ Out-links } & \multicolumn{2}{|c|}{ Out-links per page } \\
\hline & & & $\mathbf{r}$ & $f$ & $\mathbf{r}$ & f & $\mathbf{r}$ & f \\
\hline 1 & 1 & www.ru.ac.za/library & 5 & 628 & 2 & 19694 & 2 & 31.3599 \\
\hline 2 & 2 & www.cput.ac.za/library & 8 & 335 & 5 & 9774 & 3 & 29.1761 \\
\hline 3 & 3 & www.sun.ac.za/library & 3 & 917 & 3 & 16784 & 11 & 18.3032 \\
\hline 4 & 4 & www.library.und.ac.za & 10 & 218 & 7 & 9578 & 1 & 43.9358 \\
\hline 5 & 5 & www.lib.uct.ac.za & I & 16468 & I & 173616 & 22 & 10.5426 \\
\hline 6 & 6 & www.uwc.ac.za/library & 7 & 436 & 8 & 8335 & 10 & 19.1170 \\
\hline 7 & 7 & www.ufh.ac.za/library & 4 & 664 & 6 & 9658 & 18 & 14.5452 \\
\hline 8 & 8 & www.ais.up.ac.za & 2 & 1488 & 4 & 14789 & 23 & 9.9388 \\
\hline 9 & 9 & www.ub.bw/library & 14 & 49 & 11 & 1033 & 7 & 21.0816 \\
\hline 10 & 10 & www.ukzn.ac.za/westvillelibrary & 16 & 32 & 13 & 826 & 4 & 25.8125 \\
\hline II & 11 & www.wits.ac.za/library & 6 & 451 & 9 & 5320 & 19 & 11.7960 \\
\hline 12 & 12 & www.makerere.ac.ug/mulib & 13 & 55 & 12 & 911 & 12 & 16.5636 \\
\hline 13 & 13 & http://snalwww.suanet.ac.tz & 15 & 45 & 14 & 671 & 17 & $14.911 \mid$ \\
\hline 14 & 14 & http://lib.tut.ac.za & 22 & 17 & 18 & 339 & 9 & 19.9412 \\
\hline 15 & 15 & www.msu.ac.zw/libraries & 17 & 27 & 17 & 403 & 16 & 14.9259 \\
\hline 16 & 15 & www.maseno.ac.ke/library & 9 & 327 & 10 & 1340 & 31 & 4.0979 \\
\hline 17 & 16 & www.cut.ac.zw/library & 19 & 20 & 19 & 316 & 13 & 15.800 \\
\hline 18 & 17 & http://library.uonbi.ac.ke/website & 12 & 62 & 15 & 523 & 25 & 8.4355 \\
\hline 19 & 18 & www.egerton.ac.ke/academics/library & 27 & 7 & 22 & 159 & 6 & 22.7143 \\
\hline 20 & 19 & http://library.dit.ac.za & 11 & 76 & 16 & 486 & 29 & 6.3947 \\
\hline 21 & 20 & www.usiu.ac.ke/library & 18 & 21 & 20 & 196 & 24 & 9.3333 \\
\hline 22 & 21 & www.strathmore.edu/academics & 29 & 1 & 30 & 23 & 5 & 23.0000 \\
\hline 23 & 22 & www.kabarak.ac.ke/library & 26 & 8 & 24 & 125 & 14 & 15.625 \\
\hline 24 & 23 & www.anu.ac.ke/library & 17 & 27 & 21 & 185 & 27 & 6.8519 \\
\hline 25 & 24 & www.nust.ac.zw/library & 24 & 12 & 23 & $13 \mid$ & 20 & 10.9167 \\
\hline 26 & 25 & www.cut.ac.za/web/academics/library & 29 & 1 & 31 & 20 & 8 & 20.000 \\
\hline 27 & 26 & www.wsu.ac.za/library & 28 & 3 & 28 & 45 & 15 & 15.000 \\
\hline 28 & 26 & www.univen.ac.za/library & 25 & 10 & 25 & 108 & 21 & 10.8000 \\
\hline 29 & 27 & www.uj.ac.za/library & 20 & 19 & 24 & 125 & 28 & 6.5789 \\
\hline 30 & 28 & www.ueab.ac.ke/library & 23 & 13 & 27 & 90 & 26 & 6.9231 \\
\hline 31 & 29 & www.uz.ac.zw/library & 21 & 18 & 26 & 101 & 30 & 5.6111 \\
\hline 32 & 30 & www.udsm.ac.tz/library & 18 & 21 & 30 & 23 & 34 & 1.0952 \\
\hline 33 & 31 & www.unorth.ac.za/library & 25 & 10 & 29 & 24 & 33 & 2.4000 \\
\hline
\end{tabular}




\begin{tabular}{lllllllll}
34 & 31 & $w w w . c u e a . e d u / l i b r a r y$ & 19 & 20 & 32 & 19 & 36 & 0.9500 \\
35 & 32 & www.africau.edu/Library & 29 & 1 & 33 & 4 & 32 & 4.0000 \\
36 & 33 & www.mzumbe.ac.tz/library & 29 & 1 & 34 & 1 & 35 & 1.0000 \\
& TOTAL & & & $\mathbf{2 2 5 0 8}$ & $\mathbf{2 7 5 7 7 5}$ & $\mathbf{1 2 . 2 5 2 3}$ \\
\hline
\end{tabular}

Key: $r=\operatorname{rank}, f=$ frequency (i.e. number of pages, out-links and out-links per page, respectively)

6.4 Distribution of library web pages and out-links by country

The total number of library web pages and out-links were computed for each country in order to find out the most productive country. South Africa was the leading with 21793 library web pages followed by Kenya (486), Tanzania (67), Zimbabwe (58), Uganda (55) and Botswana (49). The number of out-links was highest in South Africa (269837) followed by Kenya (2660), Botswana (1033), Uganda (9II), Tanzania (695) and Zimbabwe (639). When ranked according to the average number of pages per library, South Africa was the leading with 1210.72 pages per academic library followed by Uganda (55.00), Kenya (54), Botswana (49), Tanzania (22.33), and Zimbabwe (14.50). The distribution pattern of the number of out-links per library was as follows: South Africa (14990.94), Botswana (1033.00), Uganda (911.00), Kenya (295.56), Tanzania (23I.67), and Zimbabwe (I59.75).

Table 4 Distribution of library web pages and out-links by country

\begin{tabular}{|c|c|c|c|c|c|}
\hline no. & country & pages & outlinks & pages/library & outlinks/library \\
\hline I & South Africa & 21793 & 269837 & 1210.72 & I 4990.94 \\
\hline 2 & Kenya & 486 & 2660 & 54.00 & 295.56 \\
\hline 3 & Tanzania & 67 & 695 & 22.33 & 231.67 \\
\hline 4 & Zimbabwe & 58 & 639 & 14.50 & 159.75 \\
\hline 5 & Uganda & 55 & 911 & 55.00 & 911.00 \\
\hline 6 & Botswana & 49 & 1033 & 49.00 & 1033.00 \\
\hline
\end{tabular}

6.5 Most commonly targeted web pages and Top Level Domains (TLDs)

Table 5 provides 74 top ranking sites and TLDs that are commonly targeted by the academic libraries in the region. These include, in descending order, adobe.com/ (104), nlm.nih.gov/ (103), biblioline.nisc.com/ (91), thor.sabinet.co.za/ (83), sciencedirect.com/ (69), gateway.ovid.com/ (58), serialssolutions.com/ (53) and search.rdsinc.com/ (52). Others are home.ncifcrf.gov/ (46), scirus.com/ (44), mg.co.za/ (43), isiknowledge.com/ (38), opencube.com (31), search.epnet.com/ (31). Adobe is a company that develops a variety of computer programs such as the Adobe Engagement Platform - built around Adobe PDF and Flash technology - that greatly enhances how people create, manage, deliver and engage with information. The National Library of Medicine (NLM) on the other hand, is a medical library based on the campus of the National Institutes of Health in Bethesda, Maryland. The company collects materials and provides information and research services in all areas of biomedicine and health care. One of its well known products is the MEDLINE database. The National Services Corporation (NISC, USA) provides information products that are accessed through BiblioLine, a Web search service, or on CD-ROM. BiblioLine is a straightforward yet sophisticated approach to online searching via the internet. SABINET is the short form for South African Bibliographic Network. SABINET facilitates electronic access to information, largely through the provision of bibliographies while ScienceDirect is a an online database that offers more than a quarter of the world's scientific, medical and technical information online. Its coverage include over 2,000 peerreviewed journals; hundreds of book series, handbooks and reference works; and back files.

An examination of the top level domains indicates that the .com or .co TLDs were the most common, recording 59 hits (i.e. $79.7 \%$ of the 74 top ranking sites or web pages). In the second position was .edu ( 4 or $5.4 \%$ ). The .gov, .net and .org TLDs recorded 3 hits each.

It was observed that there were a variety of sites that are targeted by E\&S African academic libraries. When classified according to the types of services or products these sites provide, the following categories emerged in the top ranking web sites: news sites (e.g. nytimes.com, daily-mail.co.zm, etc.), search engines (e.g. google.com), electronic databases (e.g. sabinet.co.za), database publishers (e.g. nlm.nih.gov, sciencedirect.com, etc), computer software companies (e.g. SA Jnl Libs \& Info Sci 2007, 73(1) 
adobe.com), government sites (e.g. gov.za), and electronic books and general reference resources (e.g. yourdictionary.com).

Table 5 Most commonly targeted web pages and TLDs

\begin{tabular}{|c|c|c|c|c|c|c|c|}
\hline No. & Rank & TLD targeted & Hits & No. & Rank & TLD targeted & Hits \\
\hline 1 & 1 & .adobe.com/ & 104 & 38 & 19 & .observer.co.uk/ & 24 \\
\hline 2 & 2 & .nlm.nih.gov/ & 103 & 39 & 19 & wwwlib.umi.com/dissertations/ & 24 \\
\hline 3 & 3 & biblioline.nisc.com/ & 91 & 40 & 20 & .library.uq.edu.au/training/ & 23 \\
\hline 4 & 4 & thor.sabinet.co.za/ & 83 & 41 & 20 & .webstat.com & 23 \\
\hline 5 & 5 & sciencedirect.com/ & 69 & 42 & 20 & .jutalaw.co.za/ & 23 \\
\hline 6 & 6 & gateway.ovid.com/ & 58 & 43 & 20 & .update-software.com/ & 23 \\
\hline 7 & 7 & serialssolutions.com/ & 53 & 44 & 20 & .rekord.co.za/ & 23 \\
\hline 8 & 8 & search.rdsinc.com/ & 52 & 45 & 20 & .safm.co.za/ & 23 \\
\hline 9 & 9 & home.ncifcrf.gov/ & 46 & 46 & 20 & .naspers.co.za/ & 23 \\
\hline 10 & 10 & $. s c i r u s . c o m /$ & 44 & 47 & 21 & .nepru.org.na & 22 \\
\hline 11 & 11 & .mg.co.za/ & 43 & 48 & 21 & .the-times.co.uk/ & 22 \\
\hline 12 & 12 & isiknowledge.com/ & 38 & 49 & 21 & .arttoday.com/ & 22 \\
\hline 13 & 13 & .opencube.com & 31 & 50 & 21 & $. s k y . c o m /$ & 22 \\
\hline 14 & 13 & search.epnet.com/ & 31 & 51 & 21 & .public.iastate.edu/ & 22 \\
\hline 15 & 14 & .nytimes.com/ & 30 & 52 & 21 & dictionary.oed.com/ & 22 \\
\hline 16 & 15 & .zoutnet.co.za/ & 28 & 53 & 22 & .paarlpost.co.za/ & 21 \\
\hline 17 & 15 & .daily-mail.co.zm/ & 28 & 54 & 23 & .sabcnews.com/ & 20 \\
\hline 18 & 15 & .zamnet.zm & 28 & 55 & 23 & .gov.za/ & 20 \\
\hline 19 & 15 & fingaz.co.zW & 28 & 56 & 23 & $. x e \cdot n e t / u c c /$ & 20 \\
\hline 20 & 16 & .memeza.com/zambia/ & 27 & 57 & 23 & .pta-online.co.za/ & 20 \\
\hline 21 & 16 & .witness.co.za/ & 27 & 58 & 23 & .portland.com/ & 20 \\
\hline 22 & 16 & .headlines.co.za/ & 27 & 59 & 24 & google.com/ & 19 \\
\hline 23 & 16 & wagne.net & 27 & 60 & 25 &. swetsnetnavigator.nl/direct/ & 18 \\
\hline 24 & 17 & .123 world.com/ & 26 & 61 & 25 & afronet.org.za/monitor.htm & 18 \\
\hline 25 & 17 & .news24.co.za/ & 26 & 62 & 25 & lexis-nexis.com/professional/ & 18 \\
\hline 26 & 17 & sowetan.co.za/ & 26 & 63 & 25 & .economist.com.na & 18 \\
\hline 27 & 17 & .jstor.org/ & 26 & 64 & 25 & .newafrica.com/ & 18 \\
\hline 28 & 18 & suntimes.co.za/ & 25 & 65 & 25 & .herald.co.zw/ & 18 \\
\hline 29 & 18 & sundaymail.co.zw/ & 25 & 66 & 25 & nigeriacentral.com/ & 18 \\
\hline 30 & 18 & .republikein.com.na & 25 & 67 & 25 & libraryspot.com/ & 18 \\
\hline 31 & 18 & .nyenzi.co.tz/ & 25 & 68 & 25 & .namibianews.com & 18 \\
\hline 32 & 18 & galenet.galegroup.com/ & 25 & 69 & 25 & nyenzi.co.tz & 18 \\
\hline 33 & 19 & library.uncg.edu/ & 24 & 70 & 25 & .yourdictionary.com/ & 18 \\
\hline 34 & 19 & .nn.independent.co.za/ & 24 & 71 & 25 & .namibian.com.na & 18 \\
\hline 35 & 19 & .time.com/time/ & 24 & 72 & 26 & wagne.net/messager & 17 \\
\hline 36 & 19 & theexpress.com & 24 & 73 & 26 & .bday.co.za/ & 17 \\
\hline 37 & 19 & .bbjonline.com/ & 24 & 74 & 26 & wisc.edu/ltc/ & 17 \\
\hline
\end{tabular}


Table 6 In- and out-links among the academic libraries in the six countries

\begin{tabular}{|c|c|c|c|c|c|c|c|c|}
\hline Name & $\begin{array}{c}\text { Page } \\
\text { inlinks }\end{array}$ & $\begin{array}{c}\text { Directory } \\
\text { inlinks }\end{array}$ & $\begin{array}{l}\text { Domain } \\
\text { inlinks }\end{array}$ & $\begin{array}{c}\text { Site } \\
\text { inlinks }\end{array}$ & $\begin{array}{c}\text { Page } \\
\text { outlinks }\end{array}$ & $\begin{array}{c}\text { Directory } \\
\text { outlinks }\end{array}$ & $\begin{array}{l}\text { Domain } \\
\text { outlinks }\end{array}$ & $\begin{array}{c}\text { Site } \\
\text { outlinks }\end{array}$ \\
\hline library.und.ac.za & 40 & 8 & 5 & 5 & 0 & 0 & 0 & 0 \\
\hline lib.uct.ac.za & 15 & 15 & 6 & 6 & 25 & 25 & 15 & 14 \\
\hline .uz.ac.zw/library & 10 & 7 & 1 & 1 & 0 & 0 & 0 & 0 \\
\hline .sun.ac.za/library & 9 & 8 & 6 & 6 & 13 & 13 & 3 & 3 \\
\hline .wits.ac.za/library & 7 & 6 & 4 & 4 & 2 & 2 & 2 & 2 \\
\hline .uwc.ac.za/library & 6 & 6 & 3 & 3 & 10 & 10 & 9 & 9 \\
\hline .univen.ac.za/library & 6 & 5 & 5 & 5 & 0 & 0 & 0 & 0 \\
\hline ais.up.ac.za & 5 & 4 & 4 & 4 & 6 & 6 & 6 & 6 \\
\hline .ru.ac.za/library & 5 & 5 & 3 & 3 & 19 & 10 & 10 & 10 \\
\hline .cput.ac.za/library & 4 & 4 & 3 & 3 & 0 & 0 & 0 & 0 \\
\hline wsu.ac.za/library & 4 & 3 & 3 & 3 & 0 & 0 & 0 & 0 \\
\hline .ukzn.ac.za/westvillelibrary & 4 & 3 & 3 & 3 & 34 & 3 & I & I \\
\hline .uj.ac.za/library & 4 & 3 & 3 & 3 & 0 & 0 & 0 & 0 \\
\hline library.dit.ac.za & 3 & 2 & 2 & 2 & 10 & 10 & 10 & 10 \\
\hline .ufh.ac.za/library & 3 & 3 & 2 & 1 & 1 & 1 & 1 & I \\
\hline .cut.ac.za/web/academics/library & 2 & 2 & 2 & 2 & 0 & 0 & 0 & 0 \\
\hline unorth.ac.za/library & 2 & 2 & 2 & 2 & 0 & 0 & 0 & 0 \\
\hline lib.tut.ac.za & 1 & 1 & 1 & 1 & 0 & 0 & 0 & 0 \\
\hline mzumbe.ac.tz/library & 1 & 1 & 1 & 1 & 0 & 0 & 0 & 0 \\
\hline makerere.ac.ug/mulib & 0 & 0 & 0 & 0 & 0 & 0 & 0 & 0 \\
\hline .ub.bw/library & 0 & 0 & 0 & 0 & 0 & 0 & 0 & 0 \\
\hline .anu.ac.ke/library & 0 & 0 & 0 & 0 & 0 & 0 & 0 & 0 \\
\hline .cuea.edu/library & 0 & 0 & 0 & 0 & 0 & 0 & 0 & 0 \\
\hline .egerton.ac.ke/academics/library & 0 & 0 & 0 & 0 & 0 & 0 & 0 & 0 \\
\hline maseno.ac.ke/library & 0 & 0 & 0 & 0 & 0 & 0 & 0 & 0 \\
\hline .ueab.ac.ke/library & 0 & 0 & 0 & 0 & 0 & 0 & 0 & 0 \\
\hline .usiu.ac.ke/library & 0 & 0 & 0 & 0 & 0 & 0 & 0 & 0 \\
\hline library.uonbi.ac.ke & 0 & 0 & 0 & 0 & 0 & 0 & 0 & 0 \\
\hline .udsm.ac.tz/library & 0 & 0 & 0 & 0 & 0 & 0 & 0 & 0 \\
\hline .africau.edu/library & 0 & 0 & 0 & 0 & 0 & 0 & 0 & 0 \\
\hline .cut.ac.zw/library & 0 & 0 & 0 & 0 & 10 & 7 & 1 & 1 \\
\hline .msu.ac.zw/libraries & 0 & 0 & 0 & 0 & 0 & 0 & 0 & 0 \\
\hline .nust.ac.zw/library & 0 & 0 & 0 & 0 & 0 & 0 & 0 & 0 \\
\hline snalwww.suanet.ac.tz & 0 & 0 & 0 & 0 & 1 & 1 & 1 & I \\
\hline .kabarak.ac.ke/library & 0 & 0 & 0 & 0 & 0 & 0 & 0 & 0 \\
\hline .strathmore.edu/academics/library.html & 0 & 0 & 0 & 0 & 10 & 8 & I & I \\
\hline Total no. of links & 150 & 99 & 61 & 60 & 150 & 99 & 61 & 60 \\
\hline Links per library & 4.17 & 2.75 & 1.69 & 1.67 & 4.17 & 2.75 & 1.69 & 1.67 \\
\hline
\end{tabular}

6.6 Number of in- and out-links among the libraries

Table 6 ranks the libraries according to the total number of page in-links. The Table provides the total number of in- and out-links (page, directory, domain, and site) that each universities received from or gave to the other universities, respectively. For instance, the UKZN [HOWARD] libraries received a total of 40 page links, 8 directory links, 5 domain links and 5 site links from the libraries that were surveyed, while it offered no out-links to any of the libraries. The UCT libraries on the other hand, provided links to other libraries as follows: 25 page and directory out-links, 15 domain outlinks and 14 site out-links. Several university libraries (e.g. MAKERERE, BU, ANU, CUEA, EGERTON, MASENO, UEAB, USIU, UDSM, AFRICAU, NUST, and KABARAK) did not receive links from nor provide links to any of the other libraries. Overall, there were a total of $150,99,61$, and 60 page, directory, domain and site in-links, respectively. On average, each 
university received and produced $4.17,2.75,1.69$, and 1.67 page, directory, domain and site out-links, respectively, as illustrated in Table 6. Another notable observation from Table 6 is that most (approximately 50\%) libraries did not have any in-links from and out-links to other libraries under the scope of this study.

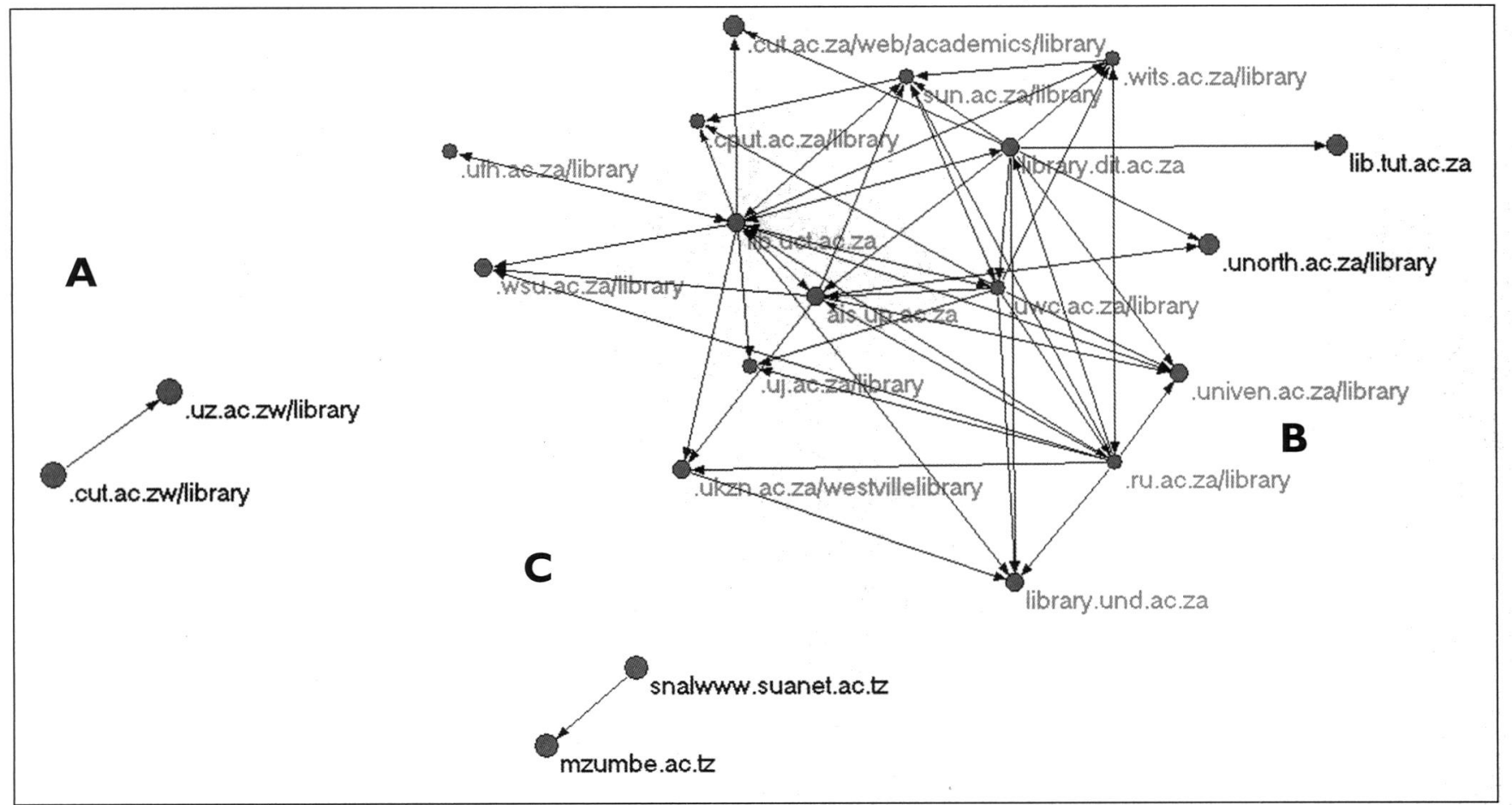

Figure 1 Academic library networks: site in- and out-links

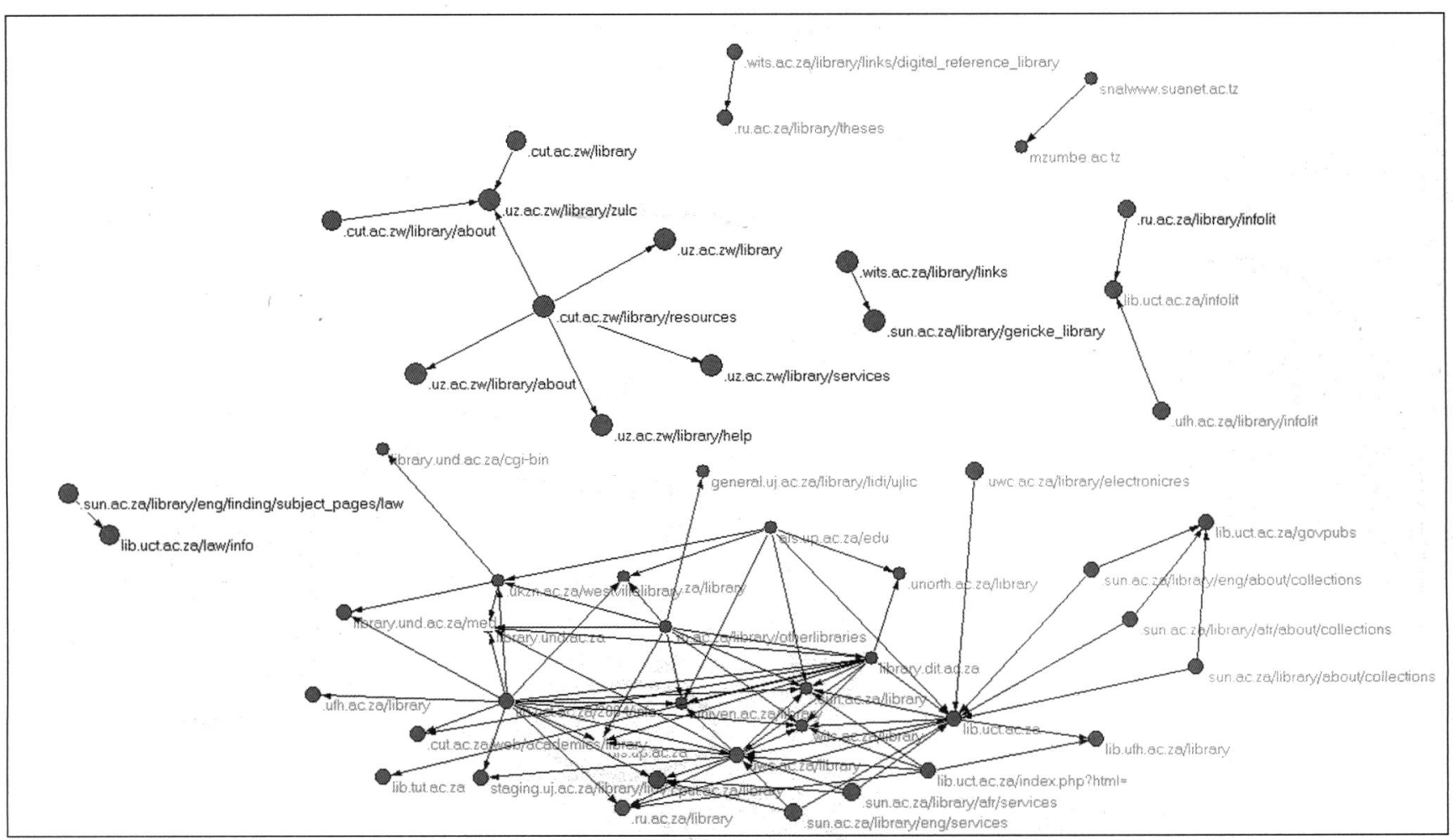

Figure 2 Academic library networks: directory in- and out-links

\subsection{Libraries' networks}

When plotted on a visual map, Table 4 above yields figures I, 2 and 3. Fig I maps the site in-links and out-links among the 36 academic libraries. The map produced three networks, marked A, B and C. A is a network of two academic libraries, namely, the UZ library and the CHINHOVI library, both found in Zimbabwe. Network B consists of 17 university libraries in South Africa while network $C$ is composed of two academic libraries in Tanzania. It can be noted that Kenya's, 
Uganda's, and Botswana's university libraries are not represented mainly because these libraries do not have any links to or from any other library investigated.

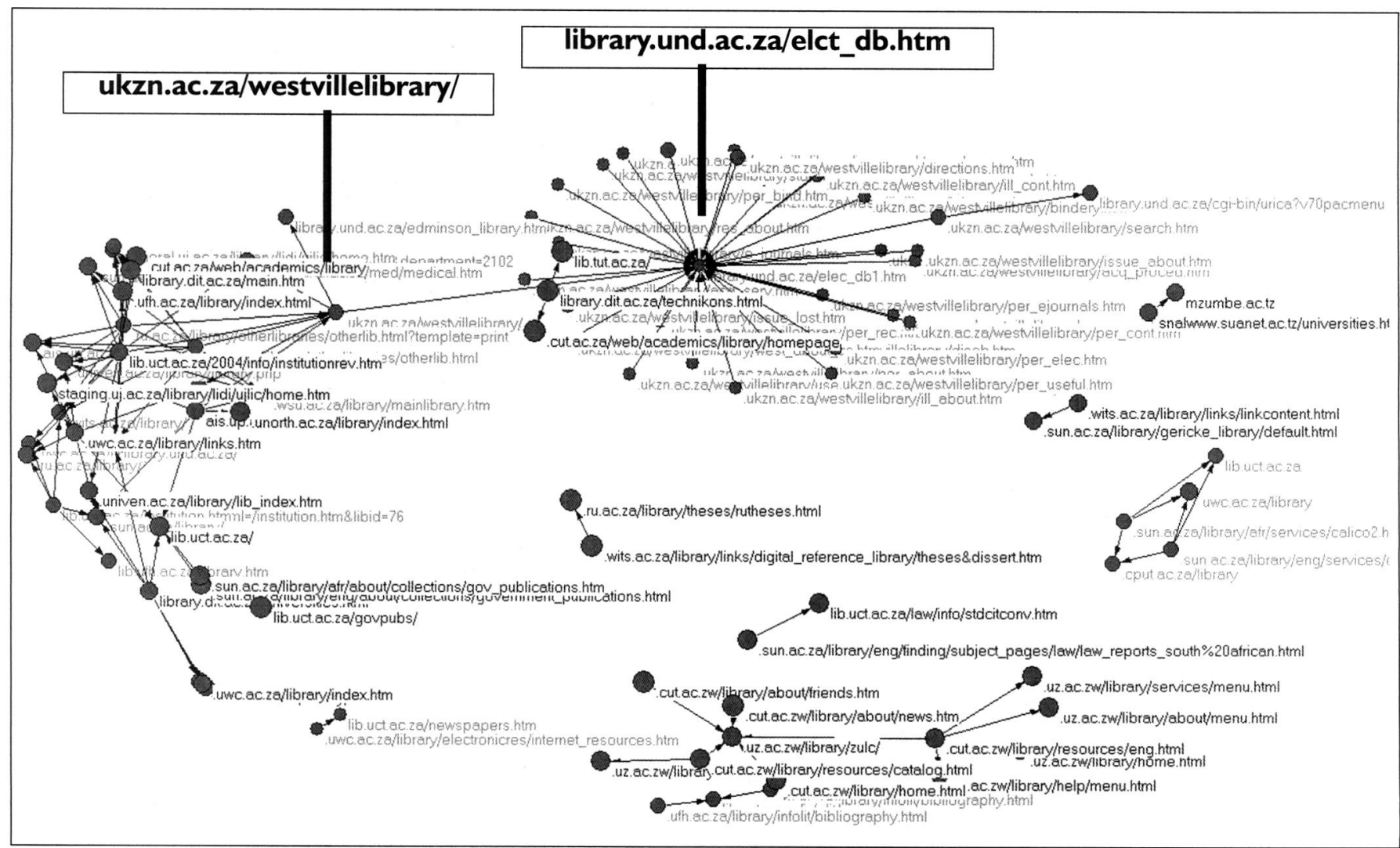

Figure 3 Academic libraries' network map: page in- and out-links

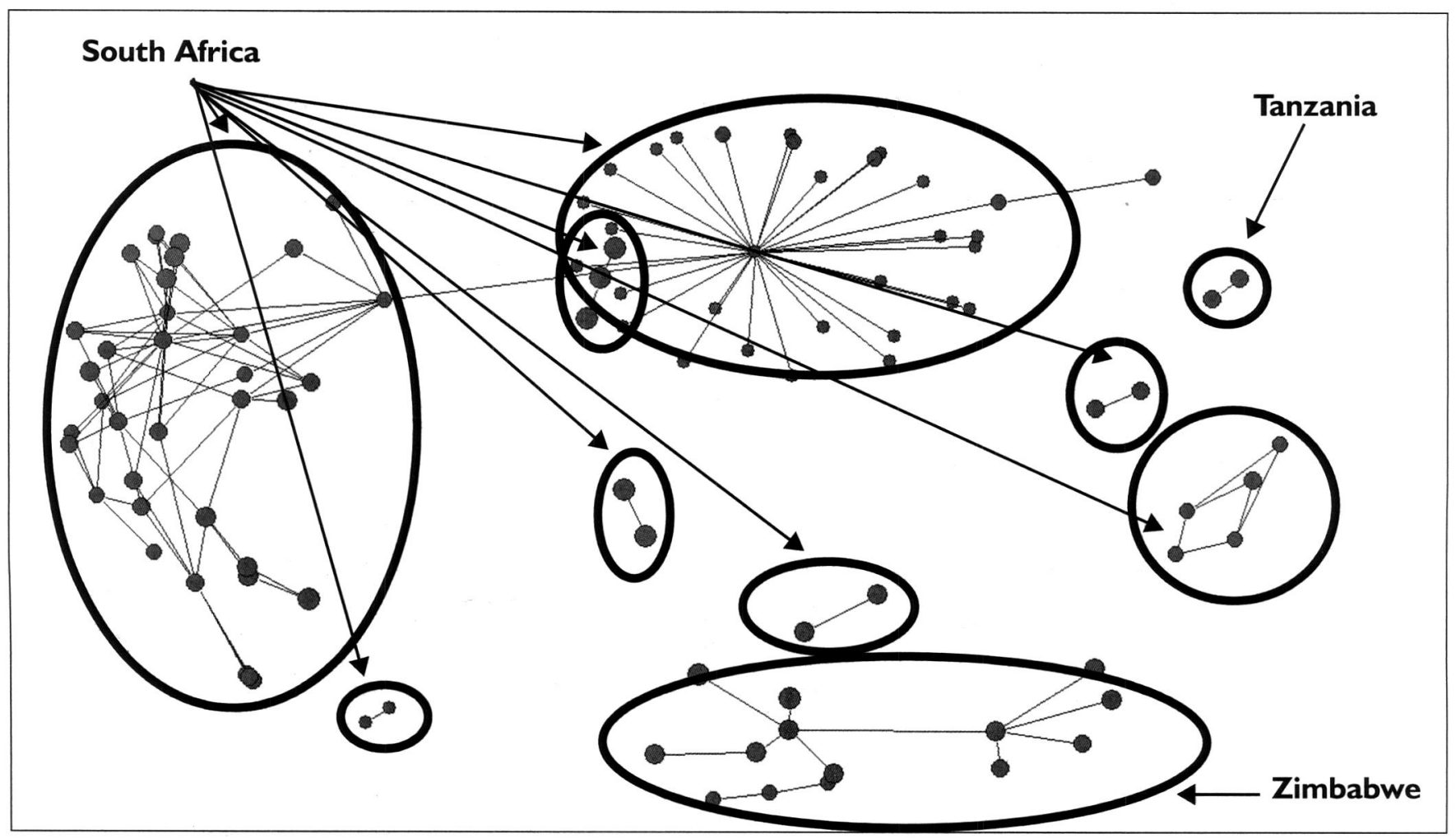

Figure 4 Academic libraries' network map: page in- and out-links 
Fig 2 is a visual presentation of the interlinkages among the libraries using directory in- and out-links. The nature of the directory links was identifiable. Some of the linked directories are concerned with library services, information about the library, information literacy, resources, digital reference library sites, electronic resources, library collections, etc.

Finally, the libraries' web pages network reveals several inter-linkages. Fig 3 and 4 provide a map of the web page linkages with and without labels, respectively. Both illustrations demonstrate dense networks that originated largely from South African academic libraries. There were a total of 8 networks belonging to libraries in South Africa while Tanzania and Zimbabwe produced one network each.

\section{Discussions, conclusions and recommendations}

Notably, libraries in Eastern and Southern Africa are well aware of the benefits and opportunities of the Internet and the Web. Despite the digital divide and technological barriers in the region, librarians in the two regions have expedited the construction of library websites. Out of a total 59 universities in the six countries that had their own websites, only 9 (15.3\%) did not have library websites. Information available from three university websites indicated that the library websites were under construction.

It is our conviction that the location of a link to the library's website on the university's website/home page should be seriously considered when designing the website especially for accessibility purposes. A library whose website is hidden is as good as a library that does not have a website. It was encouraging to note that majority of the libraries' websites had links from the respective universities' main home pages and that these links were well labeled with the term 'library'. To illustrate this more clearly, take for example a library's link that is provided on or under a university's facilities' website. Library users are left to guesswork when accessing such a library's website. Not only does this situation inconvenience a user, but can lead to non-usability of a library's services, resources and products. It was observed in this study that accessibility of three libraries' websites was a bit problematic. Links to these libraries' websites were provided under the 'academics' website. One university provided one page of a description of its library services under the directory heading 'facilities', implying that the library is just as any other facility in the university. Some of the 'other' facilities that were described alongside the library were sports and recreational facilities. It is comforting, though, to note that the university does not have a library website and perhaps that is why the university chose to provide information regarding the library in the way it did. Most probably, when the university library website is constructed, measures will be taken to appropriately provide links at the right place, preferably on the university's home page.

Concerning the provision of essential web-based services, it was noted that the online public access catalogs were the highly regarded service by the libraries most probably because they are valuable tools in accessing a library's collection. Equally seen as essential library services are the guides (or orientation and training resources). Little regard is placed on search engines. Web forms were the least popular. Whereas OPACs and guides are library-specific (i.e. specific to a library offering them), search engines and web forms are not and perhaps that explains why their provision on the libraries' websites is not deemed necessary as they can be accessed through other means. For instance, search engines such as Google can be accessed through its google.com website. However, libraries are advised to provide these services on their websites so as to make it easier for their clients to navigate the Internet from their site. Ahmed (2002:266) observes that "library users value the services that they access from their desktops because the services save time". Concerning the web forms, the author argues that web forms make it easier and convenient for users to communicate to libraries. Communication can be in the form of comments, suggestions, and requests for instruction classes, etc.

The ranking of libraries according to the total number of web pages, out-links and average out-links per page led to the following observations:

- South African university libraries performed better than their counterparts in Botswana, Kenya, Tanzania, Uganda and Zimbabwe

- No university library had a uniform rank throughout the three variables

- Libraries that had branch libraries registered higher number of pages and out-links. For instance, the Howard College Campus library of the University of KwaZulu Natal comprises four libraries, namely, EG Malherbe (Main), Barrie Biermann (Architecture), GMJ Sweeny (Law), and Eleanor Bonnar (Music) while the UCT library consists of the main library and nine branch libraries.

On overall, Rhodes University library was the top ranked followed by Cape Pennisula University library, Stellenbosch University library, KwaZulu Natal (Howard College) libraries, and University of Cape Town libraries. Perhaps librarians from other academic libraries in the region could be advised to learn from the Rhodes University library whose web performance supersedes others.

Similarly, the distribution of the total number of pages, out-links and average out-links per page showed that South Africa was the most prolific country followed by Kenya, Uganda, Botswana, Tanzania and Zimbabwe. Whether this pattern is attributable to technological advancement and/or the availability and implementation of information technology

SA JnI Libs \& Info Sci 2007, 73(I) 
and communication (ICT) policies in the respective countries was not observable from the analyzed data. But recent developments in the formulation of ICT policies in Kenya and South Africa could explain the two countries' performance. There was no information that was readily available regarding the other countries' strategies in the formulation of ICT policies.

The most commonly targeted websites and TLDs include adobe.com, nlm.nih.gov, biblionline.nisc.com, thor.sabinet.co.za, sciencedirect.com, gateway.ovid.com, serialssolutions.com, search.rdsinc.com, home.ncifcrf.gov, scirus.com, etc. Among the 74 top ranked websites and TLDs were online newspapers' sites (e.g. nytimes.com - USA, daily-mail.co.zm - Zambia, sowetan.co.za - South Africa, suntimes.co.za -South Africa, sundaymail.co.zw - Zimbabwe, etc.), electronic databases and database publishers (e.g. nlm.nih.gov, biblionline.nisc.com, sabinet.co.za, sciencedirect.com, isiknowledge.com, etc.), and book- and periodical sellers (e.g. serialssolutions.com, swetsnetnavigator.nl, etc.). This perhaps shows the importance that libraries place on electronically available resources which may have cut down the costs of subscription. Library resources (e.g. journals, magazines, books, reference materials, etc) that used to be only in print format are increasingly becoming available electronically thus changing the libraries' traditional ways of providing such products to their clients. This has called for online subscriptions to journals and other periodicals that were previously accessed through print subscriptions and perhaps the high ranking of electronic databases as the most commonly targeted sites and TLDs explains the changes that libraries are undergoing and have embraced. Accessing these resources, however, requires some computer softwares that are compatible with the formats in which they are published and that may explain adobe.com's popularity among libraries. Most full-text papers are currently published in PDF format.

Figures I, 2, 3, and 4 provide library networks based on site, directory and page in-links and out-links respectively. It was observed that South African academic libraries do have a well developed network that included all the libraries surveyed in this study. Only two libraries each from Tanzania and Zimbabwe formed networks. Contrary to expectations, none of the libraries had links with other libraries outside their geographic regions. The few networks that were generated comprised libraries from the same country. This may imply less collaborative activities between libraries in different countries, although this observation may not be necessarily true since there is "little knowledge about models and motivations of linking" (Zeinolabedinio, Maktabifard \& Osareh, 2006). However, it is well acknowledged that South African libraries do have an established inter-library cooperation and that may explain the inter-linkages that were witnessed among the libraries in the country.

Some libraries were excluded from the analysis on the basis of their website addresses which contained punctuation marks or were too long to be crawled by the personal SOCSCIBOT. Librarians are advised to provide simple and short website addresses of their libraries. Keeping the website address short and clear is very important, especially for purposes of accessibility by users. Library users may want to access the library's website by use of the library's website address and if the address is too long and/or contains some characters/symbols, it may become very difficult to memorize it, thus impeding accessibility. In addition its is recommended that

- Libraries provide space for Open Access repositories which may increase in-links

- Libraries develop useful websites that can attract users and ensure that these websites are always functional

- Libraries develop partnerships with others

- Libraries develop in-house ICT policies which can be entrenched in the main library policy(ies)

Finally, it is recommended that librarians become more involved in the construction of their libraries' websites. They should actively participate in policy formulation as regards legislation of internet-related laws and in the organization of services and resources on the internet. Libraries need to regularly update their websites to keep up with the current proliferation of Internet-based resources that are increasingly becoming freely available. For instance, the current agitation for the availability of journal articles through open access provides opportunities for libraries to improve on link development. Library cooperation (e.g. resource sharing, inter-library loans, etc) needs to be encouraged among academic libraries in Kenya, Tanzania, Uganda and Tanzania so as to improve their web linkages. Further studies are recommended so as:

I.To cover all academic libraries in Sub-Saharan Africa

2.To study the coverage of African academic libraries in major search engines and other online indexing services

3.To use other performance measurements such quality, relevance, etc. in evaluating library websites.

4. To study ICT policies that guide in the construction and maintenance of library websites in Africa

SA JnI Libs \& Info Sci 2007, 73(1) 


\section{References}

Ahmed, S.S. (2002). Managing change to enhance web-based services in the Arabian Gulf libraries. Online Information Review, 26(4): 265-270

Arte, A. (200I). The management of the scientific information environment: the role of the research library web site. Online Information Review, 25(2):88-93

Bar-llan, J. (2005). What do we know about links and linking? A framework for studying links in academic environments. Information processing and Management, 41:973-986

Booth, K. \& Napier, J. (2003). Linking people and information: web site access to National Library of New Zealand information and services. The Electronic Library, 2 I (3):227-233

Clausen, H. (1999). Evaluation of library web sites: the Danish case. The Electronic Library, I7(2): 83-87

Clyde, L.A. (2004). School library web sites: 1996-2002. The Electronic Library, 22(2): I 58-I67

Cordeiro, M.I. \& De Carvalho, J. (2002). Web services: what they are and their importance for libraries. VINE, 32(4):46-62

Covert, K. (200I). How the OCLC CORC service is helping weave libraries into the Web. Online Information Review, 25(I):4I46

Falk, H. (1999). Projecting the library onto the web. The Electronic Library, I7(6):395-399

Falk, H. (2005). State library databases on the Internet. The Electronic Library, 23(4):492-498

Henry, M. (1996). WebCATS. Campus-Wide Information Systems, I3(4): II-I 3

Hildebrand, I. (2002). The South Australian public libraries network web site (iNet): efficiencies through collaboration. Online Information Review, 26(6):375-384

Hundie, K. (2003). Library operations and library resources. The Electronic Library, 2 I (6):555-564

InterLab. 2005. Webometrics ranking of world universities. [Online]. Available http://www.webometrics.info/ (Accessed I0th April 2006)

Kennedy, P. (2004). Dynamic web pages and the library catalogue. The Electronic Library, 22(6):480-486

Kochtanek, T.R., Hein, K.K., Kassim, A.R.C. (200I). A digital library resource web site: Project DL. Online Information Review, 25(I):29-40

McCready, K. (1997). Designing and redesigning: Marquette libraries' web site. Library Hi Tech, no. 59-60:83-89

McKenna, M. (1994). Libraries and the Internet. [Online]. www.ericdigests.org Accessed 27 April 2006

Nielsen, H.J. (2005). New media and new roles of librarianship: illustrated by a literary website of Danish libraries. New Library World, 106(1218/1219):510-518

Pacios, A.R. (2003). Management-related information in Spanish university library web pages. The Electronic Library, 2I (6): 528537

Saeed, H., Asghar, M., Anwar, M. \& Ramzan, M. (2000). Internet use in university libraries of Pakistan. Online Information Review, $24(2): 154-160$

Still, J.M. (200I). A content analysis of university library web sites in English speaking countries. Online Information Review, 25(3): $160-164$

Thelwall, M. 2002a. A comparison of sources of links for academic web impact factor calculations. Journal of Documentation, $58(1): 66-78$

Thelwall, M. 2002b. An initial exploration of the link relationship between UK University Web sites. ASLIB proceedings, $54(2): 118-126$

Thelwall, M. 2002c. Evidence for the existence of geographic trends in university Web site interlinking. Journal of Documentation, 58(5):563-574

Thelwall, M. 2003. Can Google's PageRank be used to find the most important academic web pages? Journal of Documentation, 59(2):205-2I7

Westman, S. (200I). Database-backed library web pages. The Electronic Library, 19(6):424-43I

Xue, S. (2004). Web usage statistics and web site evaluation: a case study of a government publications library web site. Online information Review, 28(3): 180-190

Zeinolabedinio, M. H., Maktabifard, L. \& Osareh, F. (2006). Collaboration analysis of world national library websites via webometric methods. Proceedings on International Workshop on Webometrics, Informetrics and Scientometrics \& Seventh COLLNET Meeting, COLLNET 2006, SRDI-INIST-CNRS-LORIA Nancy, France, 10-12 May 2006. 